\title{
Androgen receptor enhancer usage and the chromatin regulatory landscape in human prostate cancers
}

\author{
Suzan Stelloo', Andries M Bergman ${ }^{2,3}$ and Wilbert Zwart ${ }^{1,4}$ \\ 1Division of Oncogenomics, Oncode Institute, The Netherlands Cancer Institute, Amsterdam, The Netherlands \\ 2Division of Oncogenomics, The Netherlands Cancer Institute, Amsterdam, The Netherlands \\ 3Division of Medical Oncology, The Netherlands Cancer Institute, Amsterdam, The Netherlands \\ ${ }^{4}$ Department of Biomedical Engineering, Laboratory of Chemical Biology and Institute for Complex Molecular Systems, Eindhoven University of \\ Technology, Eindhoven, The Netherlands
}

Correspondence should be addressed to W Zwart: w.zwart@nki.nl

\begin{abstract}
The androgen receptor (AR) is commonly known as a key transcription factor in prostate cancer development, progression and therapy resistance. Genome-wide chromatin association studies revealed that transcriptional regulation by AR mainly depends on binding to distal regulatory enhancer elements that control gene expression through chromatin looping to gene promoters. Changes in the chromatin epigenetic landscape and DNA sequence can locally alter AR-DNA-binding capacity and consequently impact transcriptional output and disease outcome. The vast majority of reports describing AR chromatin interactions have been limited to cell lines, identifying numerous other factors and interacting transcription factors that impact AR chromatin interactions. Do these factors also impact AR cistromics - the genome-wide chromatin-binding landscape of AR - in vivo? Recent technological advances now enable researchers to identify AR chromatinbinding sites and their target genes in human specimens. In this review, we provide an overview of the different factors that influence AR chromatin binding in prostate cancer specimens, which is complemented with knowledge from cell line studies. Finally, we discuss novel perspectives on studying AR cistromics in clinical samples.
\end{abstract}
Key Words
- androgen receptor
- prostate cancer
- ChIP-seq
cistrome
- subtypes

\section{Transcription factor binding}

By 2003, the DNA sequence of the entire human genome was annotated by The Human Genome Project (International Human Genome Sequencing Consortium 2004). However, as informative the primary DNA sequence information is on the protein-coding genome ( $2 \%$ of the total human DNA), interpretation of the remaining 98\% of the human genome appears more challenging. One of the major challenges in functionally interpreting the non-protein-coding human genome is that the primary sequence itself does not explain how the DNA is packaged into chromatin and where transcription factors (TFs) bind. Some TFs bind indirectly to the DNA via proteinprotein interactions by means of tethering, while other TFs recognize specific DNA sequences, often referred to as TF motifs, footprints or grammar (Fig. 1A). Many computational methods have been developed to scan for these TF motifs across the entire genome to predict the capacity of a particular TF to bind specific regions, such as (c) 2019 Society for Endocrinology Published by Bioscientifica Ltd. Printed in Great Britain
Endocrine-Related Cancer (2019) 26, R267-R285 
A

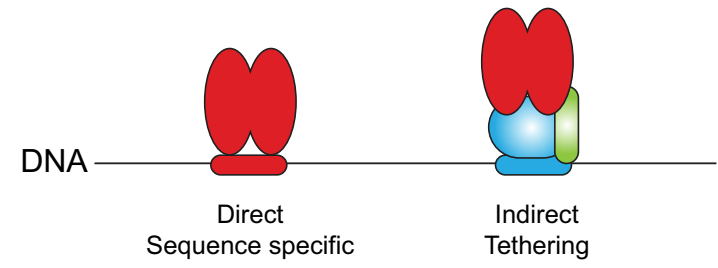

C
B

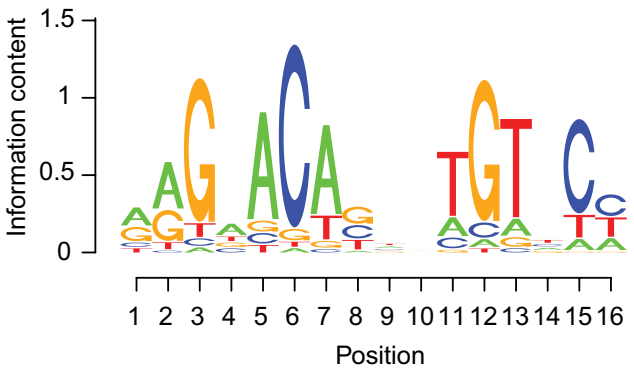

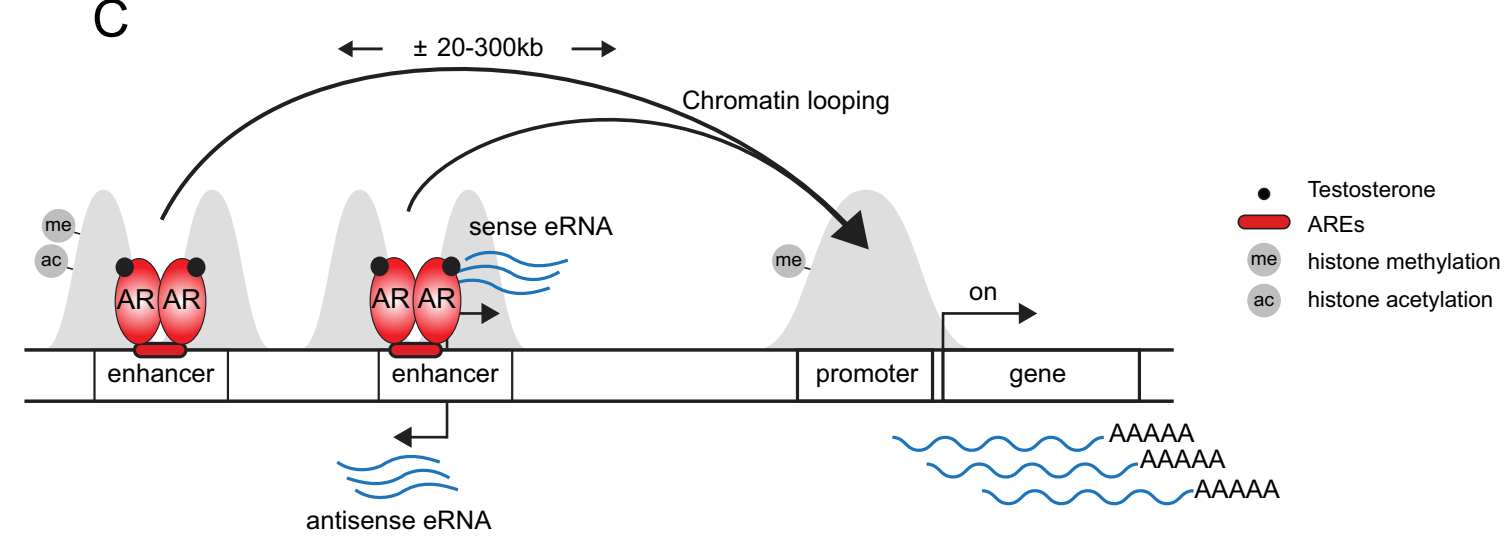

\section{Figure 1}

Transcription factor binding and transcription. (A) Transcription factors (TFs) interact with DNA to regulate gene expression. TFs can bind the DNA directly via recognition of sequence-specific elements or indirectly through other TFs. (B) Sequence logo depicting the androgen response element (ARE, MC00468). The logo is a graphical representation of a position weight matrix (PWM), which describes the nucleotide preference at each nucleotide position within the motif. (C) Graphical representation of AR-bound enhancer-promoter interaction. Accessible chromatin regions are flanked by active histone marks, such as H3K27ac at enhancers and H3K4me3 at promoters. Ligand-bound AR dimers bind to androgen-response elements (AREs) mostly at distal intergenic or intronic regions - enhancers. These enhancers are often distally located from genes with varying distances of $\sim 20-300$ kb. Some enhancers are bi-directionally transcribed to produce eRNAs.

the SeqPos motif tool (Liu et al. 2011) and HOMER (Heinz et al. 2010). In addition, other algorithms (e.g. MEME Suite; Bailey et al. 2015) can be applied to discover DNA sequence patterns in given regions. However, the presence of a TF motif does not imply that the TF is actually capable to bind this region. For example, the AR - the main driver in prostate cancer development and progression - recognizes a palindromic dihexameric androgenresponsive element (ARE), 5'-AGAACAnnnTGTTCT-3' (Fig. 1B), which occurs a few million times throughout the human genome. However, only hundreds to tens of thousands AREs appear to be functionally active in a given context and occupied by AR in prostate cell lines (Yu et al. 2010, Massie et al. 2011, Toropainen et al. 2016,

Table 1 List of AR and H3K27ac ChIP-seq datasets on human specimens.

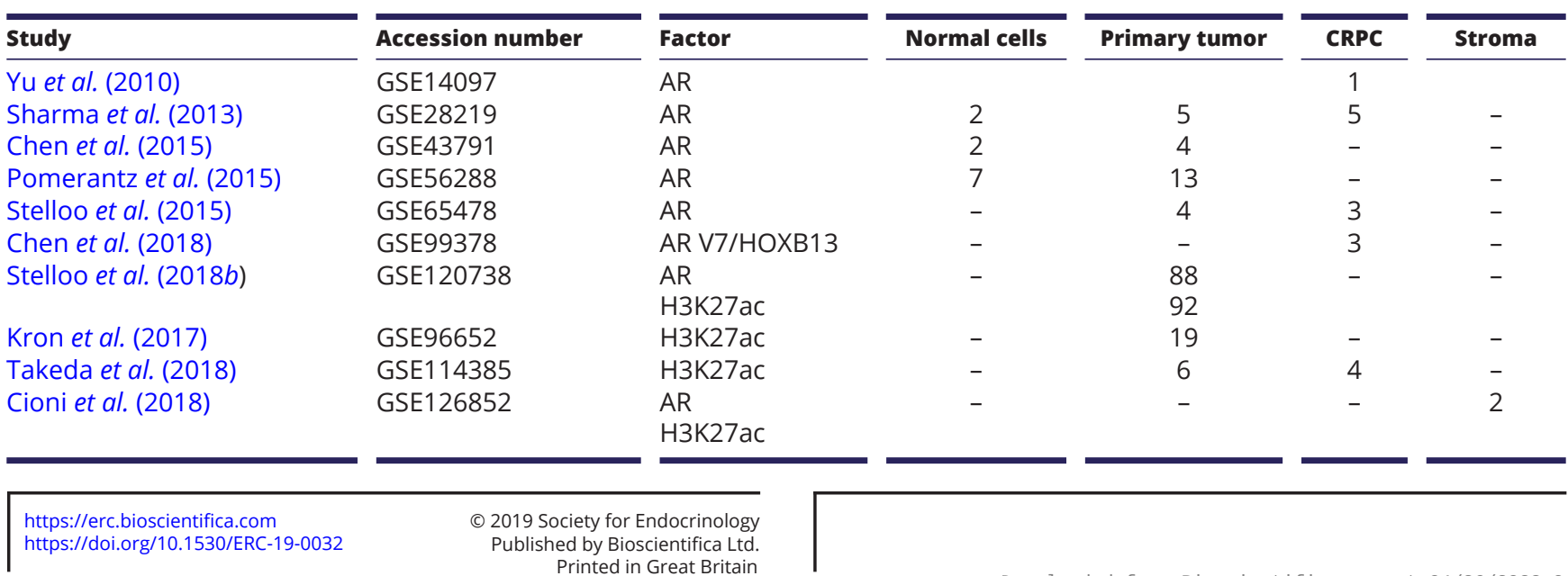


McNair et al. 2017, Stelloo et al. 2018a) and tissue samples (Sharma et al. 2013, Chen et al. 2015, Pomerantz et al. 2015, Stelloo et al. 2015, 2018b). In addition, all cells in the human body carry an identical genome; yet, TFs regulate gene expression patterns to dictate organ development and identity. Key questions to further understand AR action on a genome-wide scale are the following: Where does AR bind the genome in different contexts, and what are the biological consequences thereof? While full discussion on the biological significance of AR in prostate cancer is beyond the scope of this review, this subject has been covered elsewhere (Culig \& Santer 2014, Copeland et al. 2018, Isaacs 2018, Ken-ichi 2018). Another question is how AR chromatin binding is regulated and to what degree is this context dependent? Furthermore, with more reports describing AR cistromics in clinical samples
(Table 1), what did we learn from this, and how could we use this information in the clinical setting? In particular, we focus on the technological developments (Table 2) that have made the transition from cell line models toward the study of clinical specimens. This review will address these points systematically and will highlight the potential future research directions aimed to enhance our understanding of genome regulation in prostate cancer.

\section{AR cistromics}

\section{Where does AR bind the chromatin in cell lines?}

Prior to the era of genome-wide mapping of TF binding, AR binding was predominantly studied at the Kallikrein-3 (KLK3) gene locus, encoding the commonly used serum

Table 2 List of methods.

\begin{tabular}{|c|c|}
\hline Method & Full method name \\
\hline ChIP-on-chip & $\begin{array}{l}\text { Chromatin immunoprecipitation followed } \\
\text { by genomic tiling microarray } \\
\text { hybridization }\end{array}$ \\
\hline ChIP-seq & $\begin{array}{l}\text { Chromatin immunoprecipitation followed } \\
\text { by sequencing }\end{array}$ \\
\hline ChIP-re-ChIP & $\begin{array}{l}\text { Sequential chromatin } \\
\text { immunoprecipitations }\end{array}$ \\
\hline FFPE ChIP & $\begin{array}{l}\text { ChIP-seq analysis on formalin-fixed } \\
\text { paraffin-embedded tissue samples }\end{array}$ \\
\hline ChiA-PET & $\begin{array}{l}\text { Chromatin interaction analysis by } \\
\text { paired-end tag }\end{array}$ \\
\hline $3 C$ & Chromosome conformation capture \\
\hline $4 C$ & $\begin{array}{l}\text { Circular chromosome conformation } \\
\text { capture on chip }\end{array}$ \\
\hline MC-4C & Multicontact-4C \\
\hline $\mathrm{Hi}-\mathrm{C}$ & $\begin{array}{l}\text { Genome-wide chromatin conformation } \\
\text { capture }\end{array}$ \\
\hline $\mathrm{p}-\mathrm{CHi}-\mathrm{C}$ & Promoter capture-Hi-C \\
\hline ATAC-seq & $\begin{array}{l}\text { Assay for transposase-accessible } \\
\text { chromatin using sequencing }\end{array}$ \\
\hline RNA-seq & Ribonucleic acid sequencing \\
\hline GRO-seq & Global run-on sequencing \\
\hline RIME & $\begin{array}{l}\text { Rapid immunoprecipitation mass } \\
\text { spectrometry of endogenous protein }\end{array}$ \\
\hline qPLEX-RIME & $\begin{array}{l}\text { Quantitative multiplexed method - rapid } \\
\text { immunoprecipitation mass spectrometry } \\
\text { of endogenous protein }\end{array}$ \\
\hline WGS & Whole genome sequencing \\
\hline CRISP-seq & $\begin{array}{l}\text { Combining single-cell RNA-seq and } \\
\text { CRISPR-based perturbations }\end{array}$ \\
\hline Perturb-seq & $\begin{array}{l}\text { Combining single-cell RNA-seq and } \\
\text { CRISPR-based perturbations }\end{array}$ \\
\hline
\end{tabular}

\section{Approach for}

Genome-wide analysis of transcription

factor binding and histone modifications

Genome-wide analysis of transcription

factor binding and histone

modifications

Genome-wide analysis of co-occupancy of proteins at genomic loci

Genome-wide analysis of histone modifications using FFPE material

Protein-centered view of genome architecture

Exploring the interaction between two genomic loci (one locus to one locus)

Exploring all possible interactions with a single genomic locus (one locus to all loci)

Studying multiway chromatin interaction between many genomic loci at single allele resolution

Exploring all chromatin interactions within the genome (all loci to all loci)

$\mathrm{Hi}-\mathrm{C}$ coupled with RNA bait capture probes targeting all promoters (promoters to all loci)

Genome-wide analysis of accessible chromatin

Measuring steady-state mRNA levels Measuring nascent RNA transcripts Studying endogenous protein complexes

Studying the dynamics of endogenous protein-protein interaction

Providing the nucleotide sequence of the entire genome

Linking phenotypes at the level of the transcriptome with gene functions

Same as CRISP-seq

\section{References \\ Outdated technology AR (Takayama et al. 2007, Wang et al. 2007, 2009) \\ Barski et al. (2007)}

AR (Wang et al. 2007, Cao et al. 2014)

Fanelli et al. (2010), Cejas et al. (2016)

Fullwood et al. (2009)

AR (Zhang et al. 2019)

(Dekker et al. 2002)

Simonis et al. (2006), Zhao

et al. (2006)

Allahyar et al. (2018)

Lieberman-Aiden et al. (2009)

Schoenfelder et al. (2018)

Buenrostro et al. (2013)

Mortazavi et al. (2008)

Core et al. (2008)

Mohammed et al. (2013)

Papachristou et al. (2018)

Jaitin et al. (2016)

Dixit et al. (2016)
(C) 2019 Society for Endocrinology Published by Bioscientifica Ltd. Printed in Great Britain 
biomarker prostate-specific antigen (PSA). PSA expression was shown to be upregulated upon androgen stimulation in LNCaP cells, implicating this gene as a bonafide AR target (Young et al. 1991, Henttu et al. 1992). In response to androgens, AR along with its coregulators (Shang et al. 2002) is recruited to cis elements upstream at the promoter (ARE I and ARE II) (Pang et al. 1995, Cleutjens et al. 1996) and enhancer (ARE III) (Cleutjens et al. 1997) regions of the $K L K 3$ gene.

After extensive studies using chromatin immunoprecipitation assays (ChIP) to study AR chromatin binding at specific loci, technological advances enabled for ChIP assays followed by genomic tiling microarray hybridization (ChIP-on-chip) and later on massive parallel sequencing (ChIP-seq). These technological developments truly revolutionized the field, allowing for unbiased discovery of TF-binding sites on a genome-wide scale. The pioneering studies of AR ChIP-on-chip assays capturing $30 \mathrm{Mb}$ human genomic DNA (Takayama et al. 2007), two chromosomes (Wang et al. 2007) or the entire human genome (Wang et al. 2009) reported hormoneinduced AR-DNA binding mostly located in non-promoter proximal regions far from transcription start sites (20-50 kb). Later, AR ChIP-seq in LNCaP and VCaP cell lines confirmed that $\sim 90 \%$ of the AR-binding sites can be found at distal cis-regulatory elements (Fig. 1C) (Yu et al. 2010, Massie et al. 2011). These AR-binding events, the AR cistrome, define the transcriptional response associated with AR activation.

\section{How to identify AR target genes?}

We and others defined direct AR target genes as those genes with an AR-binding site within $20-50 \mathrm{~kb}$ of the genes (Wang et al. 2009, Sharma et al. 2013, Stelloo et al. 2015). This approach is a simple solution, but not well suited as AR-bound enhancer-target gene interaction can go far beyond a linear distance of $20-50 \mathrm{~kb}$ as recently shown for the enhancer of the $A R$ gene $(650 \mathrm{~kb})$ (Takeda et al. 2018). In addition, promoter capture Hi-C in primary hematopoietic cell types revealed a median linear distance of $331 \mathrm{~kb}$ between promoters and distal regulatory elements (Javierre et al. 2016). Furthermore, capture $\mathrm{Hi}-\mathrm{C}$ and chromatin interaction analysis by paired-end tag sequencing (ChiA-PET) revealed that one single promoter can interact with multiple enhancers, but also revealed the regulation of multiple genes by the same enhancer (Fullwood et al. 2009, Javierre et al. 2016, Zhang et al. 2019). Recently, novel methods have been developed such as multicontact $4 \mathrm{C}$ and single-cell Hi-C to rule out whether interactions co-occur simultaneously in individual cells or independently in different cells (Ramani et al. 2017, Allahyar et al. 2018). Moreover, to uncover combinatorial relationships between enhancers, several laboratories applied CRISPR genome editing or CRISPR interference (CRISPRi) to silence individual or multiple enhancer regions. These data on other steroid hormone receptors, such as the estrogen receptor alpha $(\mathrm{ER} \alpha)$ and the glucocorticoid receptor (GR), provided evidence for cooperative interaction between several hormone receptor-bound enhancers (Carleton et al. 2017, Thormann et al. 2018). It is likely that AR functions in a comparable manner, given the close homology between $\mathrm{AR}, \mathrm{GR}$ and ER, but conclusive AR-centered studies on chromatin looping are yet to be reported.

Enhancer-gene interactions can also be predicted in clinical specimens with assays, such as Hi-C and ATAC-seq (Schmitt et al. 2016, Beagrie et al. 2017, Corces et al. 2017, Diaz et al. 2018). ATAC-seq data from prostate cancer samples has become recently available (Corces et al. 2018), while $\mathrm{Hi}-\mathrm{C}$ in clinical specimens remains to be performed. ATAC-seq is a technique to assess genome-wide chromatin accessibility, and not genetic interactions per se, but enhancer-gene interactions can be studied by correlating ATAC-seq accessibility and gene expression data (Corces et al. 2018). However, Hi-C is specifically developed to measure long-range interaction on a genome-wide scale. Hi-C datasets on prostate cell lines have been generated (Rickman et al. 2012, Taberlay et al. 2016, Luo et al. 2017), albeit without hormone stimulation. Furthermore, these datasets suffer from limited resolution, which prevents functional linkage between distal regulatory elements and their target genes. Based on data from chromosome conformation capture (3C) experiments, hormone stimulation is known to enhance AR-bound enhancer looping to its target gene promoters (Wang et al. 2005, 2007, Chen et al. 2011). This is supported by genome-wide chromatin interaction studies, showing that long-range chromatin interactions exist in the absence of hormones and that the frequency of pre-existing interactions increases upon hormone (e.g. glucocorticoids) stimulation (Kuznetsova et al. 2015, D'Ippolito et al. 2018, Le Dily \& Beato 2018). It would be therefore of interest to perform for example promoter capture Hi-C, both in hormone-deprived as well as hormone-stimulated prostate cancer cell lines to characterize the AR enhancer-target gene interactome along with the potential dynamics thereof. Very recently, AR-centered chromatin interactions in VCaP cells were mapped with ChIA-PET (Zhang et al. 2019). 
However, AR ChIA-PET data in the absence of hormones would not be informative, as unliganded AR resides in the cytoplasm. Due to this limitation, AR ChIA-PET data cannot be used to assess whether these long-range interaction are de novo established upon hormone stimulations or pre-exist in the absence of hormones.

A further elucidation of direct AR target genes has been performed by combining $\mathrm{AR}$ chromatin-binding profiles with gene expression profiling. Upon androgen stimulation, hundreds to thousands of genes are being either up- or downregulated, dependent on hormone stimulation times and bioinformatics cut-offs used (DePrimo et al. 2002, Nelson et al. 2002, Hendriksen et al. 2006, Wang et al. 2007, Massie et al. 2011, Toropainen et al. 2016). Apart from protein-coding genes, non-coding transcripts are also under direct control of AR (Wang et al. 2011, Toropainen et al. 2016). Transcripts from active enhancer regions, termed enhancer RNAs (eRNAs), have been measured using Global Run-On sequencing (GRO-seq) (Fig. 1C) (Core et al. 2008). Traditional transcriptomic profiling methods (e.g. RNA-seq) cannot successfully capture these transcripts because they are very unstable. Many studies reported that eRNA levels correlated with enhancer-related chromatin features, such as H3K27ac and H3K4me1 histone modifications, and expression level of the corresponding gene (Li et al. 2016). There are enhancer-dense regions, often referred to as super-enhancers, which have exceptionally high levels of $\mathrm{H} 3 \mathrm{~K} 27 \mathrm{ac}$ as well as presence of bromodomain-containing protein 4 (BRD4), the mediator complex subunit 1 (MED1) and eRNAs (Zuber et al. 2017). Of note, the number of genome-wide AR-binding sites is considerably higher than the number of differentially expressed genes upon androgen stimulation. Moreover, merely 30\% of the AR-bound enhancers show eRNA production (Toropainen et al. 2016). This suggests that only a fraction of AR-bound enhancers are functional or that these enhancers can function without eRNA transcription. However, eRNA detection might be hindered due to their instability and/or short half-life and it remains to be determined what the functional and biological contributions are for the vast majority of eRNAs.

Multiple studies reported diverse molecular mechanisms by which eRNAs impact gene expression. eRNA binding in the histone acetyltransferase (HAT) domain of $\mathrm{CBP} / \mathrm{p} 300$ has been reported to induce their acetyltransferase activity, increasing H3K27ac level and gene expression (Bose et al. 2017). Furthermore, others showed eRNA (e.g. KLK3 eRNA) binding to cyclin T1, a member of the positive transcription elongation factor (P-TEFb) complex, leading to increased phosphorylation of RNA polymerase II to facilitate transcription (Zhao et al. 2016). Knockdown of KLK3 eRNA resulted in reduced enhancer-promoter interactions and decreased KLK3 gene transcription (Hsieh et al. 2014, Zhao et al. 2016). Cumulatively, these studies suggest that eRNAs are not merely by-products of enhancer activity, but have a functional role in hormone-regulated gene expression. Further studies of eRNAs are necessary to uncover which individual eRNAs carry what distinct biological functions.

\section{Factors affecting AR chromatin binding}

AR cistromic regulation is a tightly-orchestrated process, impacting AR-responsive genes that are selectively controlled in a cell type-specific manner to fulfill distinct biological functions in various cell types and tissues. In the case of prostate cancer, the AR cistrome is altered at different stages of disease, impacting expression of a selective repertoire of responsive genes in a contextand stage-specific manner. In normal prostate epithelial cells, AR regulates expression of genes involved in differentiation and growth suppression (Isaacs 2018). In contrast, AR signaling in prostate cancer stimulates proliferation and survival of tumor cells (Isaacs 2018). Consistent with the altered AR transcriptional program in tumorigenesis, recent ChIP-seq analysis in prostate tissue has revealed a unique AR cistrome in normal prostate tissue versus primary prostate cancers (Pomerantz et al. 2015). These AR cistromes are in part reprogrammed through the action of the TFs forkhead box protein A (FOXA1) and homeobox B13 (HOXB13). Overexpression of both FOXA1 and HOXB13 in normal prostate epithelial cells with exogenously introduced AR (LHSAR) resulted in redistribution of $\mathrm{AR}$ to genomic regions containing forkhead and homeodomain motifs, resembling an AR chromatin-binding profile as observed in human tumor specimens (Fig. 2A and B) (Pomerantz et al. 2015, Stelloo et al. 2018a). This finding is corroborated in tissue samples, where higher expression of FOXA1 and HOXB13 was observed in tumors as compared to normal tissue (Stelloo et al. 2018a). While the biological impact of FOXA1 and HOXB13 in directing AR function is slowly becoming apparent, it remains unclear how increased expression of FOXA1 and HOXB13 in prostate cancer development is regulated.
(C) 2019 Society for Endocrinology Published by Bioscientifica Ltd. Printed in Great Britain 
A
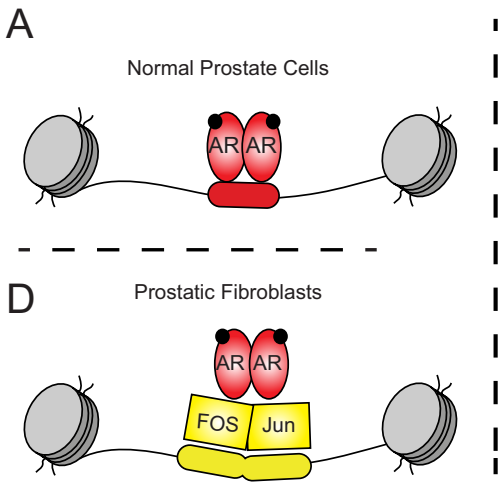

E

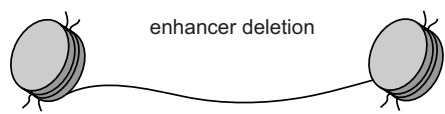

- Testosterone

* single nucleotide variant
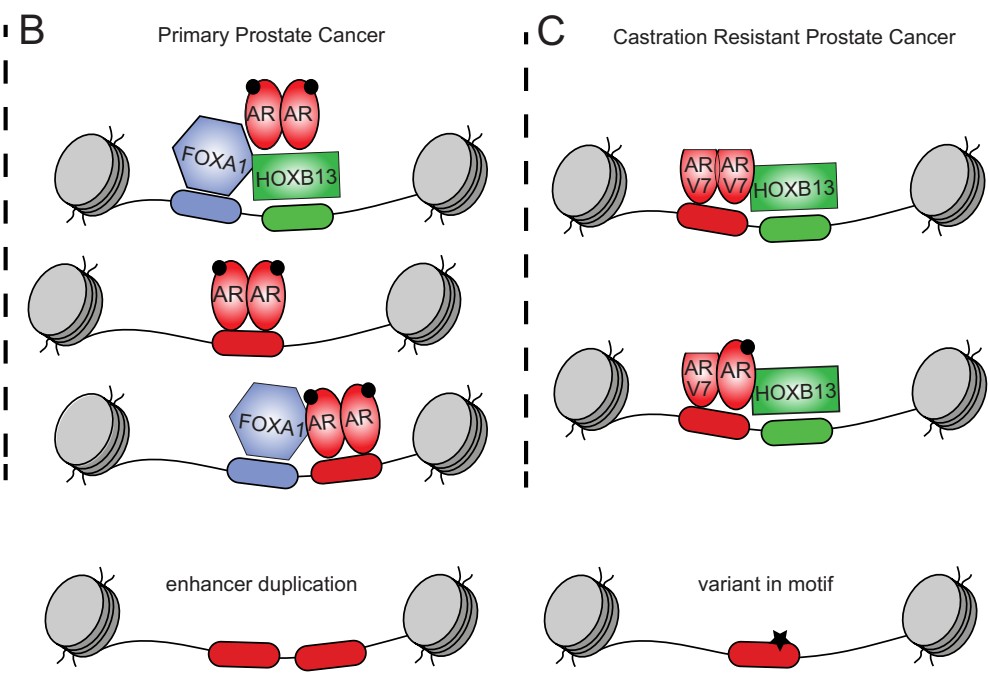

Homeobox motif

AP-1 motif

Forkhead motif

$\longrightarrow$ Androgen response element (ARE)

\section{Figure 2}

AR cistrome during disease development and progression. (A) In normal prostate epithelial cells, AR mainly occupies genomic regions containing canonical AR-binding motifs. These genomic regions are not enriched for forkhead and homeobox motifs. (B) In primary prostate cancer cells, altered expression of other transcription factors and chromatin modifiers can change the behavior of AR chromatin binding, being redistributed to genomic regions containing forkhead and homeobox motifs. (C) One potential mechanism of AR reactivation in castration-resistant prostate cancer (CRPC) cells is the expression of C-terminally truncated, constitutively active AR variants lacking the ligand-binding domain, such as AR-V7. AR-V7 can dimerize with AR full-length and also homodimerize. AR-V7 interacts with HOXB13, which regulates AR-V7 chromatin binding. (D) AR activation in prostatic fibroblasts results in recruitment of AR to the DNA by tethering to AP1 complexes. (E) Alterations in regulatory elements by deletions, amplification or mutation can impact AR-DNA binding.

\section{FOXA1}

FOXA1 is both sufficient and essential for a prostate cancer cell to adopt a 'tumor-like AR cistrome', as loss of FOXA1 expression also alters the AR cistrome repertoire in prostate cancer cell lines, as reported by three groups (Sahu et al. 2011, Wang et al. 2011, Jin et al. 2014). FOXA1 is frequently mutated in primary and metastatic castration-resistant prostate cancer (Barbieri et al. 2012, Grasso et al. 2012, Cancer Genome Atlas Research Network 2015, Robinson et al. 2015, Armenia et al. 2018), but to date, it remains elusive which effects such mutations have on the AR cistrome. The mutations in the FOXA1 gene were identified around the forkhead DNA-binding (FK) domain or in the C-terminal transactivation domain with a frequency of $3-12 \%$ in both primary prostate cancers and metastases (Barbieri et al. 2012, Grasso et al. 2012, Cancer Genome Atlas Research Network 2015, Armenia et al. 2018). The FK domain is necessary for stable FOXA1 binding to nucleosomal DNA and the C-terminal domain of the protein interacts with core histones $\mathrm{H} 3$ and $\mathrm{H} 4$ to mediate chromatin accessibility (Cirillo et al. 2002). In the TCGA cohort, primary tumors with FOXA1 mutation have been classified into one of the seven molecular subtypes, hallmarked by elevated AR target gene expression and a distinct DNA methylation profile (Cancer Genome Atlas Research Network 2015). In addition, profiling of AR, H3K27ac, H3K4me3 and H3K27me3 in primary prostate tumors identified subtype-specific chromatin landscapes, with one distinct subgroup capturing all samples bearing FOXA1 mutations (Fig. 3) (Stelloo et al. $2018 b)$. Cumulatively, these reports demonstrated that FOXA1 mutations influence AR chromatin binding and alter its downstream transcriptional profile. Further characterization of individual FOXA1 mutations is required to elucidate whether distinct mutations would differentially impact FOXA1 function and alter the AR cistrome in different ways, and whether this would impact tumorigenesis and response to hormonal therapy. In a cohort of 28 patients receiving neoadjuvant docetaxel and androgen deprivation therapy (ADT), a pathological complete response was achieved in three patients, two of which carried a FOXA1 mutation (Beltran et al. 2017). Clinical studies with information on FOXA1 mutation status are however largely underpowered, and it remains to be determined whether FOXA1 mutations would impact hormone therapy response. (c) 2019 Society for Endocrinology Published by Bioscientifica Ltd. Printed in Great Britain 


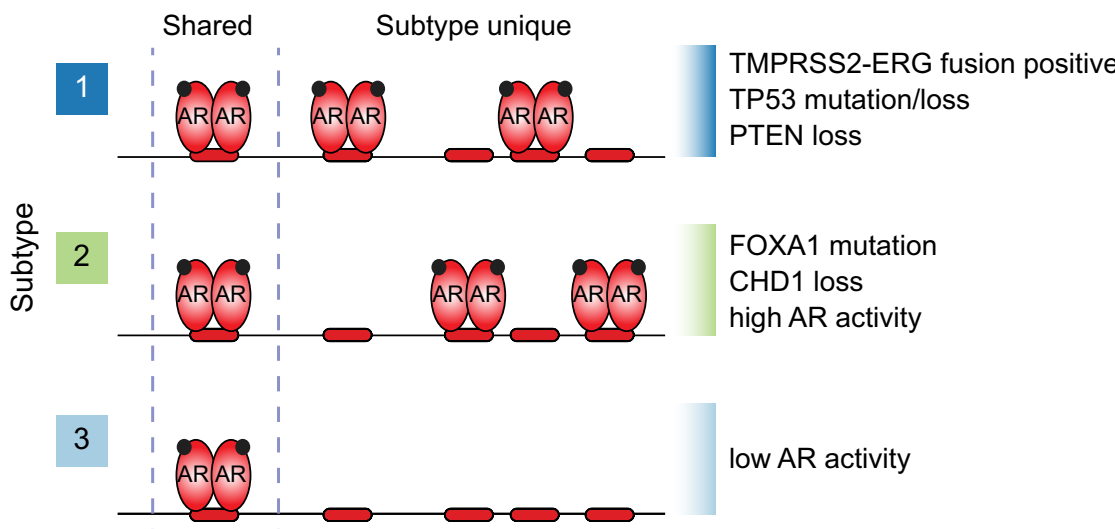

\begin{abstract}
Figure 3
Subtype-specific chromatin landscapes in primary prostate cancer. Different primary tumors can show distinct AR chromatin-binding patterns. By performing ChIP-seq on a large number of primary prostate cancer samples followed by differential binding analysis, three major subtypes were identified.
\end{abstract}

\section{HOXB13}

Homeodomain-containing proteins belong to a large class of sequence-specific TFs, of which HOXB13 is the most well studied in prostate cancer. Unlike for FOXA1, no somatic mutations in HOXB13 have been detected in primary prostate cancer or in the metastatic disease. However, a recurrent germline mutation HOXB13 (G84E) has been identified (Ewing et al. 2012), which is associated with increased prostate cancer risk (Decker \& Ostrander 2014). Recently, more hereditary HOXB13 mutations conferring increased risk of prostate cancer have been reported (Maia et al. 2015). The G84E mutation occurs in the conserved MEIS protein-binding domain; however, it does not affect HOXB13-MEIS1 interaction (Johng et al. 2019). Whether the G84E mutation affects the HOXB13-AR interactions remains elusive. From computational analyses, it is predicted that the mutation results in damaging and deleterious effects on HOXB13 DNA-binding capacity and increased stability of its protein structure (Chandrasekaran et al. 2017). While hereditary HOXB13 mutations have been extensively reported in tissue, it remains to be determined whether this mutation affects HOXB13 and/or AR chromatin binding in vitro. Especially since HOXB13 functions as a key upstream regulator of AR signaling, both for the full-length (Pomerantz et al. 2015) and AR-V7 splice variant (Chen et al. 2018) (Fig. 2C), deeper mechanistic understanding of HOXB13 action in the AR signaling axis would be highly instrumental for designing novel therapeutics that would perturb this route.

\section{ERG fusions}

In 2005, Tomlins et al. identified gene fusions of transmembrane protein serine 2 (TMPRSS2) with ETS-related gene (ERG) or ETS variant 1 (ETV1) in primary prostate cancers and cell lines, using expression outlier and RNA-exon quantification analyses (Tomlins et al. 2005). Fusions of AR-regulated genes with ETS family members occur in $\sim 50 \%$ of prostate cancers, resulting in elevated expression of these ETS TFs. ETS gene fusion-positive tumors represent a molecular subtype of prostate cancer with a distinct transcriptional profile (Tomlins et al. 2007, Setlur et al. 2008, Cancer Genome Atlas Research Network 2015). ChIP-seq experiments in cell lines revealed substantial co-occupancy of ERG and AR chromatin binding, together with transcriptional corepressors enhancer of zeste homolog 2 (EZH2) and histone deacetylases (HDACs) attenuating AR target gene expression (Kunderfranco et al. 2010, Yu et al. 2010, Chng et al. 2012). However, EZH2 has recently also been reported to activate AR signaling, which is distinct from its conventional role in epigenetic silencing (Kim et al. 2018). The non-polycomb repressive complex 2 (PRC2) function of EZH2 is consistent with previous work, which reported enriched AR motifs at EZH2-binding sites depleted of the repressive histone mark H3K27me3 (Xu et al. 2012). Besides ERG-induced transcriptional repression, ERG overexpression also redistributes HOXB13, FOXA1 and AR to novel regulatory elements marked by H3K27ac and H3K4me1 (Chen et al. 2013, Kron et al. 2017). In addition, ChIP-seq profiles for AR, H3K27ac and H3K27me3 ChIP-seq profiles stratified primary prostate cancers on ERG fusion status (Fig. 3) (Kron et al. 2017, Stelloo et al. 2018b). The profoundly different ChIP-seq and transcriptome profiles are accompanied with distinct DNA methylation patterns and changes in 3D chromatin conformation (Rickman et al. 2012, Kron et al. 2013, Geybels et al. 2015). The latter is based on Hi-C analysis in the benign prostate epithelial cell line RWPE1, but recent technological advancements (Schmitt et al. 2016, Beagrie et al. 2017, Diaz et al. 2018) now enable the study of chromatin conformation in human tissue to reflect a more clinically relevant scenario. 
The widespread chromatin and transcriptional alterations as seen in ERG fusion-positive prostate cancers render ERG and its downstream targets highly interesting targets for therapy (Kron et al. 2017, Wang et al. 2017).

\section{CHD1}

One other frequent alteration reported in primary prostate cancer is loss of chromodomain helicase DNA-binding protein 1 (CHD1), which is mostly observed in ERG fusion-negative tumors and not ERG fusion-positive tumors. The mutual exclusivity of $C H D 1$ loss with $E R G$ rearrangements might be explained by the fact that loss of $C H D 1$ acts synthetically lethal with loss of phosphatase and tensin homolog (PTEN) in human prostate cancer cell lines (Zhao et al. 2017), and PTEN loss frequently co-occurs with $E R G$ gene fusion (Taylor et al. 2010). However, this result was not observed in murine prostates, where loss of CHD1 and PTEN led to the development of invasive carcinoma, while CHD1 loss alone was insufficient to drive tumorigenesis (Augello et al. 2019). The cause of this discrepancy is unknown, although speculative it may arise from mouse/human species differences.

Knockdown of CHD1 prevents androgen-induced chromosomal rearrangement resulting in the absence of TMPRSS2-ERG fusion transcripts (Burkhardt et al. 2013, Metzger et al. 2016). This finding might be explained by the role of CHD1 in DNA repair. Both non-homologous end joining (NHEJ) and homologs recombination (HR) DNA repair processes are involved in transcription-associated DNA damage, but which repair pathway is affected by CHD1 is still under debate (Hedayati et al. 2016, Kari et al. 2016, Shenoy et al. 2017). In addition to its role in DNA repair, CHD1 maintains chromatin in an accessible state for $\mathrm{AR}$ and other TF to bind. Knockdown of CHD1 impairs AR recruitment to promoters of AR-responsive genes (KLK3, TMPRSS2, FKBP5, ELK4 and KLK2) (Burkhardt et al. 2013). The genome-wide experiments further demonstrated overlapping CHD1- and AR chromatinbinding sites (Metzger et al. 2016, Augello et al. 2019). In addition, a large proportion of the CHD1 chromatinassociated protein complex represents members of the AR interactome, suggesting a role of CHD1 in AR signaling. Indeed, loss of CHD1 was recently reported to rewire AR signaling by redistributing AR binding to HOXB13enriched sites (Augello et al. 2019). This was confirmed with AR ChIP-seq on tissue samples deficient for CHD1 (Fig. 3) (Augello et al. 2019).

Previous work demonstrated that a substantial number of AR-binding sites are accessible prior to

(c) 2019 Society for Endocrinology Published by Bioscientifica Ltd. Printed in Great Britain hormone stimulation, while other sites become accessible after hormone stimulation (He et al. 2012, Tewari et al. 2012), providing a plausible explanation why not all AR sites are affected by CHD1 loss. However, whether tumors with loss of CHD1 have distinct nucleosome remodeling patterns needs to be determined.

\section{Others}

Genetic alterations in other epigenetic regulators, including Lysine (K)-specific methyltransferase 2C (KMT2C) and zinc finger MYM-type containing 3 (ZMYM3), are less frequent in primary prostate cancer (Barbieri et al. 2012, Cancer Genome Atlas Research Network 2015). Nonetheless, the interplay between AR and epigenetic pathways as well as studies on other hormone receptors hint toward a role of these proteins in AR biology. For example, knockdown of KMT2C in breast cancer cells has been shown to suppress estrogen-dependent gene expression via loss of H3K4me1 and H3K27ac selectively at ER $\alpha$ enhancers (Jozwik et al. 2016, Gala et al. 2018). However, KMT2C knockdown did not result in a major loss of ER $\alpha$ chromatin binding but likely impairs recruitment of cofactors to the ER $\alpha$ complex (Gala et al. 2018). Indeed, the recruitment of cofactors to AR-bound enhancers is crucial for AR-mediated transcriptional activation or repression. New technologies such as rapid immunoprecipitation mass spectrometry of endogenous protein (RIME) (Mohammed et al. 2013) led to increased knowledge of the AR-enhanceosome - the protein complex at AR-bound enhancers. We and others have identified novel AR protein interactions in prostate cancer cell lines (Paltoglou et al. 2017, Stelloo et al. 2018a); however, the functional impact of all newly identified AR interaction partners still needs to be unraveled. A recently developed technique, quantitative multiplexed method (qPLEX-RIME) (Papachristou et al. 2018), may shed light on the composition of these AR multiprotein complexes in human tissue samples.

\section{Factors affecting AR chromatin binding in castration-resistant prostate cancer}

Castration-resistant prostate cancer (CRPC) refers to the disease stage in which the tumor progresses despite reduced serum testosterone levels due to ADT. As a consequence of selection pressure from ADT or anti-androgens on AR signaling axis, AR-dependent resistance mechanisms emerge including AR amplification, overexpression, somatic point mutations and constitutively active splice 
variants (Claessens et al. 2014). Moreover, genome-wide selectivity of AR-binding patterns has been reported in CRPC (Sharma et al. 2013, Stelloo et al. 2015), suggesting CRPC-specific factors to configure AR reprogramming.

\section{AR amplifications}

AR amplifications are significantly enriched in metastatic CRPC as compared to primary prostate cancer. These AR amplifications involve copy number gain of the AR enhancer (Fig. 2E), the $A R$ gene or both resulting in increased AR expression (Takeda et al. 2018, Viswanathan et al. 2018). In vitro, overexpression of AR allows the cells to activate AR signaling in low androgen environment resulting in increased AR chromatin-binding sites and downstream regulated genes (Urbanucci et al. 2012). Whether this effect is also observed in clinical samples remains to be determined.

\section{AR splice variants}

Besides AR amplification, treatment selection pressure by ADT induces aberrant AR mRNA splicing. Over 20 $\mathrm{AR}$ variants are described to date, including the most intensively studied variant AR-V7. AR-V7 is hardly expressed in primary prostate cancer samples and associated with increased total AR expression (Sharp et al. 2018, He et al. 2018). As overall AR is often overexpressed in $\mathrm{CRPC}, \mathrm{AR}-\mathrm{V7}$ is consequently more frequently observed in CRPC samples as well. Most models studied thus far either express full-length AR or a variant, which does not represent the clinical situation where different types of AR-Vs are often simultaneously coexpressed with full-length AR. With the development of AR-V specific antibodies, it is now possible to perform ChIP-seq with AR-V-specific antibodies and C-terminal antibodies to distinguish the variant from the full length in more physiologically relevant model systems as well as in human specimens (Chen et al. 2018).

As AR-V7 lacks the ligand-binding domain, the receptor is constitutively active, with nuclear localization and chromatin binding in the absence of ligand. AR-V7 mostly binds regions with canonical AREs, as a homodimer (Fig. 2C) (Chan etal. 2015, He etal. 2018). In addition, AR-V7 and full-length AR have been reported to heterodimerize, as determined with ChIP-re-ChIP experiments (Cao et al. 2014) and co-immunoprecipitations (He et al. 2018). AR-V7 chromatin binding appeared to be less dependent on FOXA1, but rather selectively dependent on HOXB13 for its chromatin interactions instead (He et al. 2018).
In line with this, silencing of HOXB13 significantly decreases AR-V7 chromatin binding (Chen et al. 2018). Whether this is unique to AR-V7 could not be addressed, as full-length AR protein levels were significantly decreased in HOXB13-silenced LNCaP cells causing examination of full-length AR cistrome non-informative (Pomerantz et al. 2015).

Multiple reports have shown AR-V7 preferential chromatin-binding sites and differential gene expression as compared to full-length AR (Hu et al. 2012, Cao et al. 2014, Krause et al. 2014, Lu et al. 2015, He et al. 2018), but this was contradicted by one other study (Chan et al. 2015). These AR-V7 gene signatures as well as the expression of AR-V7 itself are associated with disease progression (Lu et al. 2015, Sharp et al. 2018). However, it remains unclear whether AR-V7 contributes to resistance. Although AR-V7 is a predictive biomarker for conventional AR-targeted therapies, most likely because cells expressing AR full length are sensitive to castration and antiandrogen treatment, whereas AR-V7-expressing cells are indifferent to therapy (Guo et al. 2009, Chan et al. 2015). Therefore, the next challenge is discovering and testing AR-V7-targeted therapies, such as alternative druggable regions on AR or by targeting its cofactors. Dalal et al. recently published compounds that block the AR-DNA-binding domain (DBD) dimerization interface, inhibiting both AR and AR variant transcriptional activity (Dalal et al. 2018). Targeting other functional domains such as the transactivation domain are promising as well, for example, the EPI compounds of which EPI-506 is currently evaluated in a phase I dose escalation clinical trial (NCT02606123) (Andersen et al. 2010). Besides small molecules, an alternative approach can be the expression of decoy peptides representing the AR N-terminal domain. These decoys have been shown to inhibit both androgendependent prostate cancer and CRPC growth, most likely by competitive binding to AR-interacting proteins required for AR transcriptional activity (Quayle et al. 2007, Myung et al. 2017). In fact, many more inhibitors targeting the AR have been reported and are reviewed by others (Centenera et al. 2018).

\section{Single nucleotide variants in enhancers}

Another level of AR cistrome deregulation is reflected in single nucleotide variants (SNVs), including SNPs and somatic point mutations at cis-regulatory elements (Fig. 2E). With the growing number of genomewide association studies (GWAS) and whole genome (c) 2019 Society for Endocrinology Published by Bioscientifica Ltd. Printed in Great Britain 
sequencing (WGS) efforts, millions of SNVs have been identified, most with unknown significance and $>90 \%$ found in non-protein regions (1000 Genomes Project Consortium et al. 2012, Baca et al. 2013, Espiritu et al. 2018, Quigley et al. 2018, Schumacher et al. 2018). Interestingly, prostate cancer risk SNPs are found enriched at enhancer elements including those bound by AR (Lu et al. 2012, Bu et al. 2016, Whitington et al. 2016, Dadaev et al. 2018). Causal regulatory SNPs altering AR binding has been demonstrated in the enhancer of sex determining region Y box 9 (SOX9) gene (Zhang et al. 2012), an intron of the melanophilin (MLPH) gene (Bu et al. 2016) and the promoter of KLK3 (Lai et al. 2007). Moreover, an increased mutational load proximal to AR-binding sites and other transcriptional regulators such as HOXB13 and FOXA1 has been reported (Mazrooei et al. 2018, Morova et al. 2017). However, only $20 \%$ of the somatic SNVs which lie within regulatory elements marked with H3K27ac and binding of AR, FOXA1, HOXB13 are predicted to impact binding of these TFs (Mazrooei et al. 2018). Knowing whether a regulatory SNV potentially disrupts or creates new binding sites would aid to elucidate their target genes and their potential functional impact on prostate cancer. In addition, in vitro validation of these variants would be crucial to distinguish driver events from non-pathogenic passenger variants. As it is difficult to study the consequence of variants on TF binding in clinical samples, a functional impact of variants is generally studied by computational approaches and/or in vitro experimental methodologies. Given the growing number of genomic datasets (e.g. ATAC-seq, WGS, ChIP-seq) on clinical samples, it may become possible in the future to functionally connect variants with TF binding in human tumor samples, although larger sample sizes with matched genomic datasets would be required. Using computational approaches, TF-DNAbinding specificity can be estimated based on deviations of the position weight matrices (PWM) (Fig. 1B), which is a matrix of scores which correspond to the frequencies of the nucleotides at each position in the TF motif (Deplancke et al. 2016) Other methods rely on integration of multidimensional data including accessible chromatin regions, chromatin marks and TF-binding profiles (Deplancke et al. 2016). Furthermore, to functionally validate the significance of SNVs on TF binding in vitro, typically assays such as electrophoretic mobility shift assays (EMSA) are used, aimed to study DNA-protein interactions as well as luciferase reporter assays. Recently, the development of a massively parallel reporter assay made it possible to test different SNVs simultaneously, as shown for red blood cell trait-associated variants (Ulirsch et al. 2016). Additionally, the advent of CRISPR technology enables the study of variants in a native genomic context either by editing one single locus or by performing enhancer screens. Using the latter strategy, Korkmaz et al. identified ER $\alpha$-binding sites that are required for breast cancer proliferation (Korkmaz et al. 2016). Given the work on ER $\alpha$, the very same approach can be applied to analyze AR-binding sites and thereby infer causal SNVs. Alternatively, one can envision a genetic screen targeting AR-bound enhancers with transcriptional profiles as readout to infer enhancer-target gene pairs with methods such as Perturb-seq (Dixit et al. 2016) or CRISP-seq (Jaitin et al. 2016) which combine CRISPR-based perturbations with single-cell RNA-seq. This framework has recently been shown to be successful in detecting enhancer-gene pairs (Xie et al. 2017, Gasperini et al. 2019). Such efforts for AR-binding sites will characterize downstream biological consequences of genetic variants.

\section{Larger cistromic datasets}

In this review, several factors have been described that influence AR-binding patterns in prostate cancer. While original reports were largely focused on cell lines, gradually an increasing body of evidence is being generated that study AR chromatin binding in clinical specimens. This transition to tumor material is of added value for multiple reasons. First, cell lines are (albeit powerful and extremely useful) just a model that would always require further validation in a physiologically more-relevant setting. Secondly, in order to draw conclusions in cell lines for eventual translation of such concepts to clinical implementation, validation of such basic biology observations in tissue specimens is a crucial intermediate step. Lastly, as prostate cancer is considered a heterogeneous disease with multiple genomic (Cancer Genome Atlas Research Network 2015) and epigenetic (Stelloo et al. 2018b) subtypes, and the biological complexity of the disease is not fully covered by the limited set of available cell line models.

Large-scale ChIP-seq datasets on patient cohorts can help to better understand prostate cancer subtype-specific chromatin landscapes in a tissue context. Many AR-binding sites are patient specific (inter-individual heterogeneity), but defining common features of chromatin landscapes shared among tumors is helpful for defining subtypes. Determining subtype-specific chromatin landscapes requires differential binding algorithms such as DiffBind (c) 2019 Society for Endocrinology Published by Bioscientifica Ltd. Printed in Great Britain 
(Ross-Innes et al. 2012), a ranking normalization strategy (Patten et al. 2018), ChromHMM followed by MCA (multiple correspondence analysis) factorial analysis (Lomberk et al. 2018) or matrix factorization algorithms (Stelloo et al. 2018b). New bioinformatic tools and pipelines continue to emerge, aimed to ingrate both epigenetic and genomics data to better understand specific phenotypes. Analysis of 100 primary prostate cancers revealed a relationship between chromatin landscapes and their regulation of gene expression associated with three subtypes (Fig. 3) (Stelloo et al. 2018b). In addition, two main prostate cancer subtypes related to $E R G$ gene fusions were identified. These results are consistent with previous prostate cancer profiling studies (see above; ERG), but the results also provided unique insights, such as the discovery of a third subtype. Tumors classified in this subtype have a low AR pathway activity as reflected by the low number of AR-binding sites and low AR activity score. This opens new avenues for therapeutic decisions as tumors with low AR activity score are more prone to develop resistance to hormone therapy (Spratt et al. 2018).

Whereas the studies so far focused on inter-individual chromatin landscape variability, studying one tumor/ single foci of one patient, the intra-tumor heterogeneity remains to be explored. This is of special interest as the majority of primary prostate cancers harbor multiple tumor foci (Andreoiu \& Cheng 2010). These foci revealed differences on the level of gene expression, DNA methylation, copy number and mutation status (Boutros et al. 2015, Mundbjerg et al. 2017, Espiritu et al. 2018), suggesting that the observed variation might also be reflected in the chromatin landscape. Improvement of ChIP efficiency on limited quantities of tissues (Dahl \& Gilfillan 2018, Singh et al. 2019) holds great promise to study multiple clones and also infer relationship between primary tumor foci and metastatic lesions with respect to the chromatin landscape. Another undoubted advancement is the usage of formalin-fixed paraffinembedded (FFPE) specimens for ChIP (Fanelli et al. 2010, Cejas et al. 2016), which has been successfully applied to study histone marks but not yet TFs.

\section{AR cistrome-based classifiers for patient stratification}

Even though AR chromatin binding in primary prostate cancer specimens is a determinant of the genomic landscape of prostate cancer subtypes, these binding sites did not appear to be associated with patient outcome
(Stelloo et al. 2018b). However, a subset of AR-binding sites, identified through differential binding analysis in benign versus primary prostate cancer or primary prostate cancer versus progressive disease bear prognostic potential (Sharma et al. 2013, Chen et al. 2015, Pomerantz et al. 2015, Stelloo et al. 2015). To be more specific, actually the genes proximal to these AR-binding sites were tested and validated for their prognostic potential. Even though promising, as for example, our 9-gene expression signature was able to identify patients with an ultra-high risk to develop biochemical recurrence after radical prostatectomy (Stelloo et al. 2015); none of these classifiers are used in daily clinical practice yet. Application of classifiers based on differentially bound regions rather than genes would be costly and laborious, limiting the application of ChIP-based classifiers in clinical practice. The establishment of an automated workflow for both ChIP and library preparation would render the approach more cost-effective and robust. For example, a method such as ChIP-string, which is a modified NanoString's nCounter Analysis System platform to measure enriched genomic DNA of loci of interest from ChIP experiments (Ram et al. 2011), would be more suitable for clinical application.

Clinically useful interpretation of cistrome-based classifiers requires appropriate pathology review, as bulk tumor and normal tissue samples will have varying degrees of epithelial content and stromal contamination. Fibroblasts, the most abundant cell type in stroma, express AR albeit at lower levels as compared to prostate epithelial cells (Leach et al. 2017, Cioni et al. 2018, Nash et al. 2018). In fibroblasts, it was shown that AR chromatin binding is disparate from epithelial AR cistrome, with preferential AR binding at sites enriched for motifs of FOS and JUN family members (Leach et al. 2017, Cioni et al. 2018). Knockdown of Jun reduced AR binding at three loci (Leach et al. 2017), but whether this affects global AR binding remains to be addressed. However, the data suggest that $\mathrm{AR}$ binding in prostate fibroblasts is dependent on the AP1 complex, a complex consisting of homo/heterodimer combinations of FOS and JUN members, rather than classical pioneer factors such as FOXA1 (Fig. 2D). This phenomenon of enrichment of other motifs than AREs, forkhead and homeodomain motifs, is also seen in AR ChIP-seq on human caput epididymis (Yang et al. 2018) and mouse kidney and epididymis (Pihlajamaa et al. 2014). These observed tissue-specific AR cistromes achieved by collaborating factors further supports a rationale to study $\mathrm{AR}$ cistromes in other cells of the tumor microenvironment. 


\section{Future perspectives}

Although ChIP-seq studies using human specimens have provided a more detailed understanding of $\mathrm{AR}$ chromatin binding in prostate cancer, a lot remains to be explored (Fig. 4). Comparative studies of AR cistromes can be expanded to metastatic lesions and larger cohorts to provide clues on AR functioning and its target genes during prostate cancer progression. Collecting the primary tumor(s) as well as the metastases during disease progression and at time of death is of great interest, enabling the identification of AR cistrome characteristics of the primary tumor lesion that ultimately gave rise to the lethal metastatic lesion. Despite limited to one case, Haffner et al. defined the origin of metastatic lesions by performing WGS on primary prostate foci and metastasis (Haffner et al. 2013). In addition, evaluation of AR cistromes from samples collected before, on and after treatment (NCT03297385), as well after acquisition of treatment resistance will provide valuable information to better understand how AR signaling is associated with disease progression. We can learn from research on ER $\alpha$ chromatin binding in breast specimens before and after neoadjuvant tamoxifen treatment (Severson et al. 2016), where drug-induced changes in ER $\alpha$ chromatin binding were observed.

Another interesting approach, applicable for patients with large burden of ctDNA, could be identification of nucleosome footprints in ctDNA. Analysis of two plasma samples taken 12 months apart, during which the prostate adenocarcinoma transdifferentiated to a treatmentemergent small-cell neuroendocrine prostate carcinoma (t-SCNC, AR-independent disease state), showed no longer accessibility of AR-binding sites during the disease course (Ulz et al. 2018). Given the paucity of serial sample collections at different points during the disease course, alternative models such as patient-derived xenografts (PDX), ex vivo cultures and/or cell lines are required to monitor therapy effect on transcription factor dynamics.

The analysis of 100 primary prostate cancers is the largest AR cistromic dataset on prostate cancer (Stelloo et al. 2018b) and no such large cistromic data sets of $\mathrm{ER} \alpha$ in breast cancer exist yet. Future research of ideally larger sample sizes for breast cancer may be considered to study cistrome differences underlying clinical and genetic features of breast cancer subtypes.

In the era of single-cell genomics, advanced approaches enable complete characterization of the genome, transcriptome and epigenome at the single-cell level. This will enable us to assess cellular heterogeneity, cells in the tumor microenvironment and clinical specimens with too low tumor cell percentage for bulk sequencing. Also, a single-cell ChIP-seq (scChIP-seq) protocol has been published (Rotem et al. 2015), but is yet to be validated. With improvement in throughput, quantitation and sensitivity, scChIP-seq might become more valuable to analyze cell-to-cell variability in chromatin landscapes across a population. Ultimately, combining different single-cell methods to investigate for example epigenetic and transcriptome correlation

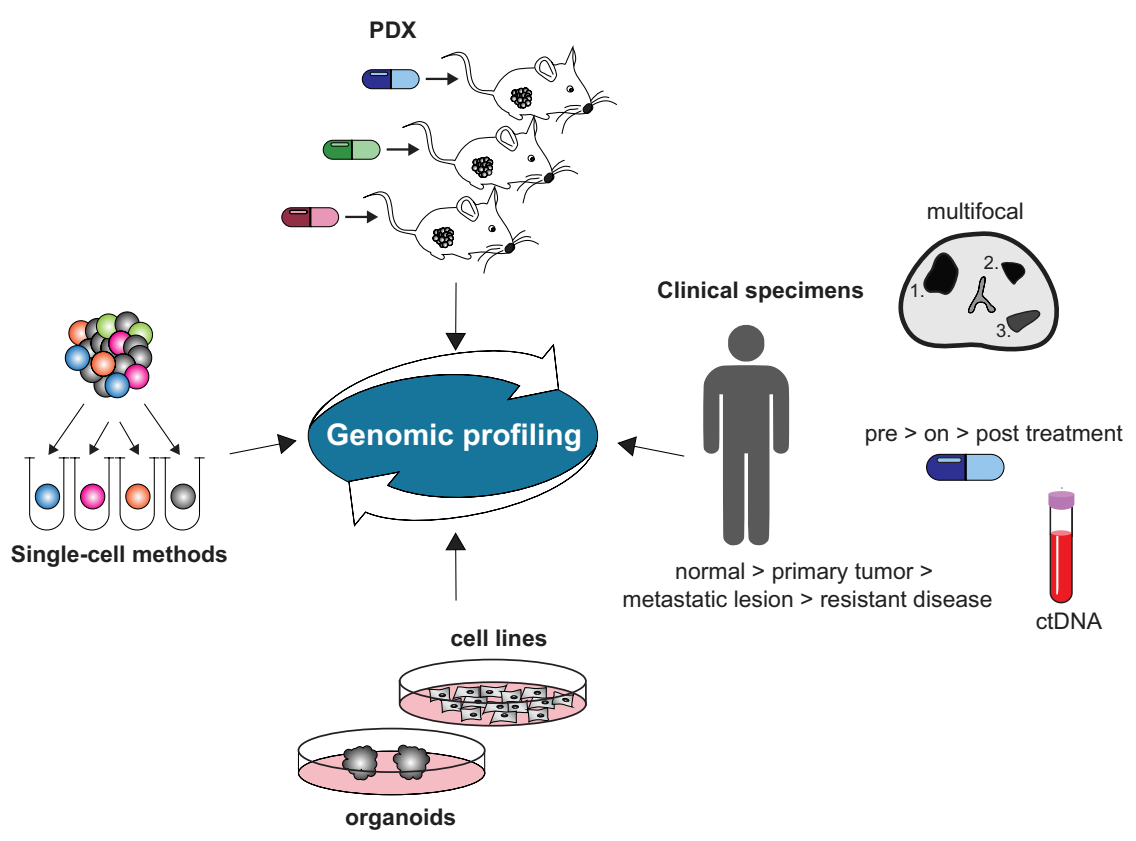

\section{Figure 4}

Future directions. Schematic illustration of models for addressing AR genomics in prostate cancer development and progression. The cellular model systems (patient-derived xenograft (PDX), organoids and cell lines) offer an unprecedented opportunity to assess the effect of various drugs, different stimuli and other perturbations (e.g. CRISPR experiments) on the genomic landscape. The use of human specimens will allow us to relate genomic results to clinical outcome at various stages of the disease. Complementing genomics with advances in single-cell approaches can provide insights into the genomic landscape of heterogeneous tumors and cells of the tumor microenvironment. 
and how these are associated with cellular phenotypes will lead towards a comprehensive understanding of the behavior of individual cells in prostate cancer.

\section{Conclusions}

To date, the vast majority of functional genomic studies on AR have used a limited panel of cell line models. Due to improved technological advances, a comprehensive understanding of AR together with a detailed picture of the epigenomic landscapes in prostate cancer specimens is beginning to emerge. Research has highlighted the involvement of numerous features beyond sequence motifs alone to be involved in AR cistrome reprogramming, such as ERG fusions and TF overexpression (e.g. FOXA1 and HOXB13). Further characterization of mechanisms underlying AR reprogramming during prostate tumorigenesis and progression - from normal to prostatic intraepithelial neoplasia, metastatic and therapy-resistant disease - will enable identification of affected target genes. Identification of those genes may enhance the translational potential of ChIP-seq data. This will stimulate the discovery of promising targets for therapeutic intervention and new biomarkers of early detection and resistance.

\section{Declaration of interest}

The authors declare that there is no conflict of interest that could be perceived as prejudicing the impartiality of this review.

\section{Funding}

This work was supported by funding from Movember (NKI01), KWF Dutch Cancer Society (10084 ALPE), KWF Dutch Cancer Society/Alpe d'HuZes Bas Mulder Award (NKI 2014-6711) and a VIDI grant (016.156.401) from The Netherlands Organisation for Scientific Research (NWO).

\section{Acknowledgements}

The authors would like to thank Simon Linder for critical review of the manuscript.

\section{References}

1000 Genomes Project Consortium, Abecasis GR, Auton A, Brooks LD, DePristo MA, Durbin RM, Handsaker RE, Kang HM, Marth GT \& McVean GA 2012 An integrated map of genetic variation from 1092 human genomes. Nature 491 56-65. (https://doi.org/10.1038/ nature11632)
Allahyar A, Vermeulen C, Bouwman BAM, Krijger PHL, Verstegen MJAM, Geeven G, van Kranenburg M, Pieterse M, Straver R, Haarhuis JHI, et al. 2018 Enhancer hubs and loop collisions identified from singleallele topologies. Nature Genetics 50 1151-1160. (https://doi. org/10.1038/s41588-018-0161-5)

Andersen RJ, Mawji NR, Wang J, Wang G, Haile S, Myung JK, Watt K, Tam T, Yang YC, Banuelos CA, et al. 2010 Regression of castraterecurrent prostate cancer by a small-molecule inhibitor of the amino-terminus domain of the androgen receptor. Cancer Cell $\mathbf{1 7}$ 535-546. (https://doi.org/10.1016/j.ccr.2010.04.027)

Andreoiu M \& Cheng L 2010 Multifocal prostate cancer: biologic, prognostic, and therapeutic implications. Human Pathology 41 781-793. (https://doi.org/10.1016/j.humpath.2010.02.011)

Armenia J, Wankowicz SAM, Liu D, Gao J, Kundra R, Reznik E, Chatila WK, Chakravarty D, Han GC, Coleman I, et al. 2018 The long tail of oncogenic drivers in prostate cancer. Nature Genetics $\mathbf{5 0}$ 645-651. (https://doi.org/10.1038/s41588-018-0078-z)

Augello MA, Liu D, Deonarine LD, Robinson BD, Huang D, Stelloo S, Blattner M, Doane AS, Wong EWP, Chen Y, et al. 2019 CHD1 loss alters AR binding at lineage-specific enhancers and modulates distinct transcriptional programs to drive prostate tumorigenesis. Cancer Cell [epub]. (https://doi.org/10.1038/ng.2279)

Baca SC, Prandi D, Lawrence MS, Mosquera JM, Romanel A, Drier Y, Park K, Kitabayashi N, MacDonald TY, Ghandi M, et al. 2013 Punctuated evolution of prostate cancer genomes. Cell 153 666-677. (https://doi.org/10.1016/j.cell.2013.03.021)

Bailey TL, Johnson J, Grant CE \& Noble WS 2015 The MEME suite. Nucleic Acids Research 43 W39-W49. (https://doi.org/10.1093/nar/ gkv416)

Barbieri CE, Baca SC, Lawrence MS, Demichelis F, Blattner M, Theurillat JP, White TA, Stojanov P, Van Allen E, Stransky N, et al. 2012 Exome sequencing identifies recurrent SPOP, FOXA1 and MED12 mutations in prostate cancer. Nature Genetics 44 685-689. (https://doi.org/10.1038/ng.2279)

Barski A, Cuddapah S, Cui K, Roh TY, Schones DE, Wang Z, Wei G, Chepelev I \& Zhao K 2007 High-resolution profiling of histone methylations in the human genome. Cell 129 823-837. (https://doi. org/10.1016/j.cell.2007.05.009)

Beagrie RA, Scialdone A, Schueler M, Kraemer DC, Chotalia M, Xie SQ, Barbieri M, de Santiago I, Lavitas LM, Branco MR, et al. 2017 Complex multi-enhancer contacts captured by genome architecture mapping. Nature 543 519-524. (https://doi.org/10.1038/ nature21411)

Beltran H, Wyatt AW, Chedgy EC, Donoghue A, Annala M, Warner EW Beja K, Sigouros M, Mo F, Fazli L, et al. 2017 Impact of therapy on genomics and transcriptomics in high-risk prostate cancer treated with neoadjuvant docetaxel and androgen deprivation therapy. Clinical Cancer Research 23 6802-6811. (https://doi. org/10.1158/1078-0432.CCR-17-1034)

Bose DA, Donahue G, Reinberg D, Shiekhattar R, Bonasio R \& Berger SL 2017 RNA binding to CBP stimulates histone acetylation and transcription. Cell 168 135.e22-149.e22. (https://doi.org/10.1016/j. cell.2016.12.020)

Boutros PC, Fraser M, Harding NJ, de Borja R, Trudel D, Lalonde E, Meng A, Hennings-Yeomans PH, McPherson A, Sabelnykova VY, et al. 2015 Spatial genomic heterogeneity within localized, multifocal prostate cancer. Nature Genetics 47 736-745. (https://doi. org/10.1038/ng.3315)

Bu H, Narisu N, Schlick B, Rainer J, Manke T, Schafer G, Pasqualini L, Chines P, Schweiger MR, Fuchsberger C, et al. 2016 Putative prostate cancer risk SNP in an androgen receptor-binding site of the melanophilin gene illustrates enrichment of risk SNPs in androgen receptor target sites. Human Mutation 37 52-64. (https://doi. org/10.1002/humu.22909)

Buenrostro JD, Giresi PG, Zaba LC, Chang HY \& Greenleaf WJ 2013 Transposition of native chromatin for fast and sensitive epigenomic (c) 2019 Society for Endocrinology Published by Bioscientifica Ltd. Printed in Great Britain 
profiling of open chromatin, DNA-binding proteins and nucleosome position. Nature Methods 10 1213-1218. (https://doi.org/10.1038/ nmeth.2688)

Burkhardt L, Fuchs S, Krohn A, Masser S, Mader M, Kluth M, Bachmann F, Huland H, Steuber T, Graefen M, et al. 2013 CHD1 is a 5q21 tumor suppressor required for ERG rearrangement in prostate cancer. Cancer Research 73 2795-2805. (https://doi.org/10.1158/00085472.CAN-12-1342)

Cancer Genome Atlas Research Network 2015 The molecular taxonomy of primary prostate cancer. Cell 163 1011-1025. (https://doi. org/10.1016/j.cell.2015.10.025)

Cao B, Qi Y, Zhang G, Xu D, Zhan Y, Alvarez X, Guo Z, Fu X, Plymate SR, Sartor O, et al. 2014 Androgen receptor splice variants activating the full-length receptor in mediating resistance to androgen-directed therapy. Oncotarget 5 1646-1656. (https://doi. org/10.18632/oncotarget.1802)

Carleton JB, Berrett KC \& Gertz J 2017 Multiplex enhancer interference reveals collaborative control of gene regulation by estrogen receptor alpha-bound enhancers. Cell Systems 5 333.e335-344.e335. (https:// doi.org/10.1016/j.cels.2017.08.011)

Cejas P, Li L, O’Neill NK, Duarte M, Rao P, Bowden M, Zhou CW, Mendiola M, Burgos E, Feliu J, et al. 2016 Chromatin immunoprecipitation from fixed clinical tissues reveals tumorspecific enhancer profiles. Nature Medicine 22 685-691. (https://doi. org/10.1038/nm.4085)

Centenera MM, Selth LA, Ebrahimie E, Butler LM \& Tilley WD 2018 New opportunities for targeting the androgen receptor in prostate cancer. Cold Spring Harbor Perspectives in Medicine 8 a030478. (https:// doi.org/10.1101/cshperspect.a030478)

Chan SC, Selth LA, Li Y, Nyquist MD, Miao L, Bradner JE, Raj GV, Tilley WD \& Dehm SM 2015 Targeting chromatin binding regulation of constitutively active AR variants to overcome prostate cancer resistance to endocrine-based therapies. Nucleic Acids Research $\mathbf{4 3}$ 5880-5897. (https://doi.org/10.1093/nar/gkv262)

Chandrasekaran G, Hwang EC, Kang TW, Kwon DD, Park K, Lee JJ \& Lakshmanan VK 2017 Computational modeling of complete HOXB13 protein for predicting the functional effect of SNPs and the associated role in hereditary prostate cancer. Scientific Reports 7 43830. (https://doi.org/10.1038/srep43830)

Chen Y, Chi P, Rockowitz S, Iaquinta PJ, Shamu T, Shukla S, Gao D, Sirota I, Carver BS, Wongvipat J, et al. 2013 ETS factors reprogram the androgen receptor cistrome and prime prostate tumorigenesis in response to PTEN loss. Nature Medicine 19 1023-1029. (https://doi. org/10.1038/nm.3216)

Chen Z, Lan X, Thomas-Ahner JM, Wu D, Liu X, Ye Z, Wang L, Sunkel B, Grenade C, Chen J, et al. 2015 Agonist and antagonist switch DNA motifs recognized by human androgen receptor in prostate cancer. EMBO Journal 34 502-516. (https://doi.org/10.15252/ embj.201490306)

Chen Z, Wu D, Thomas-Ahner JM, Lu C, Zhao P, Zhang Q Geraghty C, Yan PS, Hankey W, Sunkel B, et al. 2018 Diverse AR-V7 cistromes in castration-resistant prostate cancer are governed by HoxB13. PNAS 115 6810-6815. (https://doi. org/10.1073/pnas.1718811115)

Chen Z, Zhang C, Wu D, Chen H, Rorick A, Zhang X \& Wang Q 2011 Phospho-MED1-enhanced UBE2C locus looping drives castrationresistant prostate cancer growth. EMBO Journal 30 2405-2419. (https://doi.org/10.1038/emboj.2011.154)

Chng KR, Chang CW, Tan SK, Yang C, Hong SZ, Sng NY \& Cheung E 2012 A transcriptional repressor co-regulatory network governing androgen response in prostate cancers. EMBO Journal 31 2810-2823. (https://doi.org/10.1038/emboj.2012.112)

Cioni B, Nevedomskaya E, Melis MHM, van Burgsteden J, Stelloo S, Hodel E, Spinozzi D, de Jong J, van der Poel $\mathrm{H}$, de Boer JP, et al. 2018 Loss of androgen receptor signaling in prostate cancerassociated fibroblasts (CAFs) promotes CCL2- and CXCL8-mediated cancer cell migration. Molecular Oncology 12 1308-1323. (https://doi. org/10.1002/1878-0261.12327)

Cirillo LA, Lin FR, Cuesta I, Friedman D, Jarnik M \& Zaret KS 2002 Opening of compacted chromatin by early developmental transcription factors HNF3 (FoxA) and GATA-4. Molecular Cell 9 279-289. (https://doi.org/10.1016/S1097-2765(02)00459-8)

Claessens F, Helsen C, Prekovic S, Van den Broeck T, Spans L, Van Poppel H \& Joniau S 2014 Emerging mechanisms of enzalutamide resistance in prostate cancer. Nature Reviews Urology 11 712-716. (https://doi.org/10.1038/nrurol.2014.243)

Cleutjens KB, van der Korput HA, van Eekelen CC, van Rooij HC, Faber PW \& Trapman J 1997 An androgen response element in a far upstream enhancer region is essential for high, androgen-regulated activity of the prostate-specific antigen promoter. Molecular Endocrinology 11 148-161. (https://doi.org/10.1210/mend.11.2.9883)

Cleutjens KB, van Eekelen CC, van der Korput HA, Brinkmann AO \& Trapman J 1996 Two androgen response regions cooperate in steroid hormone regulated activity of the prostate-specific antigen promoter. Journal of Biological Chemistry 271 6379-6388. (https://doi. org/10.1074/jbc.271.11.6379)

Copeland BT, Pal SK, Bolton EC \& Jones JO 2018 The androgen receptor malignancy shift in prostate cancer. Prostate 78 521-531. (https:// doi.org/10.1002/pros.23497)

Corces MR, Granja JM, Shams S, Louie BH, Seoane JA, Zhou W, Silva TC, Groeneveld C, Wong CK, Cho SW, et al. 2018 The chromatin accessibility landscape of primary human cancers. Science $\mathbf{3 6 2}$ eaav1898. (https://doi.org/10.1126/science.aav1898)

Corces MR, Trevino AE, Hamilton EG, Greenside PG, SinnottArmstrong NA, Vesuna S, Satpathy AT, Rubin AJ, Montine KS, Wu B, et al. 2017 An improved ATAC-seq protocol reduces background and enables interrogation of frozen tissues. Nature Methods 14 959-962. (https://doi.org/10.1038/nmeth.4396)

Core LJ, Waterfall JJ \& Lis JT 2008 Nascent RNA sequencing reveals widespread pausing and divergent initiation at human promoters. Science 322 1845-1848. (https://doi.org/10.1126/science.1162228)

Culig Z \& Santer FR 2014 Androgen receptor signaling in prostate cancer. Cancer Metastasis Reviews 33 413-427. (https://doi. org/10.1007/s10555-013-9474-0)

Dadaev T, Saunders EJ, Newcombe PJ, Anokian E, Leongamornlert DA, Brook MN, Cieza-Borrella C, Mijuskovic M, Wakerell S, Olama AAA, et al. 2018 Fine-mapping of prostate cancer susceptibility loci in a large meta-analysis identifies candidate causal variants. Nature Communications 9 2256. (https://doi.org/10.1038/s41467-018-04109-8)

Dahl JA \& Gilfillan GD 2018 How low can you go? Pushing the limits of low-input ChIP-seq. Briefings in Functional Genomics 17 89-95. (https://doi.org/10.1093/bfgp/elx037)

Dalal K, Morin H, Ban F, Shepherd A, Fernandez M, Tam KJ, Li H, LeBlanc E, Lack N, Prinz H, et al. 2018 Small molecule-induced degradation of the full length and V7 truncated variant forms of human androgen receptor. European Journal of Medicinal Chemistry 157 1164-1173. (https://doi.org/10.1016/j.ejmech.2018.08.059)

Decker B \& Ostrander EA 2014 Dysregulation of the homeobox transcription factor gene HOXB13: role in prostate cancer. Pharmacogenomics and Personalized Medicine 7 193-201. (https://doi. org/10.2147/PGPM.S38117)

Dekker J, Rippe K, Dekker M \& Kleckner N 2002 Capturing chromosome conformation. Science 295 1306-1311. (https://doi.org/10.1126/ science.1067799)

Deplancke B, Alpern D \& Gardeux V 2016 The genetics of transcription factor DNA binding variation. Cell 166 538-554. (https://doi. org/10.1016/j.cell.2016.07.012)

DePrimo SE, Diehn M, Nelson JB, Reiter RE, Matese J, Fero M, Tibshirani R, Brown PO \& Brooks JD 2002 Transcriptional programs activated by exposure of human prostate cancer cells to androgen. Genome Biology 3 RESEARCH0032. (https://doi.org/10.1186/gb-20023-7-research0032) https://erc.bioscientifica.com

https://doi.org/10.1530/ERC-19-0032
C) 2019 Society for Endocrinology Published by Bioscientifica Ltd. Printed in Great Britain 
Diaz N, Kruse K, Erdmann T, Staiger AM, Ott G, Lenz G \& Vaquerizas JM 2018 Chromatin conformation analysis of primary patient tissue using a low input Hi-C method. Nature Communications 94938. (https://doi.org/10.1038/s41467-018-06961-0)

D'Ippolito AM, McDowell IC, Barrera A, Hong LK, Leichter SM, Bartelt LC, Vockley CM, Majoros WH, Safi A, Song L, et al. 2018 Pre-established chromatin interactions mediate the genomic response to glucocorticoids. Cell Systems 7 146.e7-160.e7. (https:// doi.org/10.1016/j.cels.2018.06.007)

Dixit A, Parnas O, Li B, Chen J, Fulco CP, Jerby-Arnon L, Marjanovic ND, Dionne D, Burks T, Raychowdhury R, et al. 2016 Perturb-seq: dissecting molecular circuits with scalable single-cell RNA profiling of pooled genetic screens. Cell 167 1853.e17-1866. e17. (https://doi.org/10.1016/j.cell.2016.11.038)

Espiritu SMG, Liu LY, Rubanova Y, Bhandari V, Holgersen EM, Szyca LM, Fox NS, Chua MLK, Yamaguchi TN, Heisler LE, et al. 2018 The evolutionary landscape of localized prostate cancers drives clinical aggression. Cell 173 1003.e15-1013.e15. (https://doi.org/10.1016/j. cell.2018.03.029)

Ewing CM, Ray AM, Lange EM, Zuhlke KA, Robbins CM, Tembe WD, Wiley KE, Isaacs SD, Johng D, Wang Y, et al. 2012 Germline mutations in HOXB13 and prostate-cancer risk. New England Journal of Medicine 366 141-149. (https://doi.org/10.1056/NEJMoa1110000)

Fanelli M, Amatori S, Barozzi I, Soncini M, Dal Zuffo R, Bucci G, Capra M, Quarto M, Dellino GI, Mercurio C, et al. 2010 Pathology tissue-chromatin immunoprecipitation, coupled with highthroughput sequencing, allows the epigenetic profiling of patient samples. PNAS 107 21535-21540. (https://doi.org/10.1073/ pnas.1007647107)

Fullwood MJ, Liu MH, Pan YF, Liu J, Xu H, Mohamed YB, Orlov YL, Velkov S, Ho A, Mei PH, et al. 2009 An oestrogen-receptor-alphabound human chromatin interactome. Nature 462 58-64. (https:// doi.org/10.1038/nature08497)

Gala K, Li Q, Sinha A, Razavi P, Dorso M, Sanchez-Vega F, Chung YR, Hendrickson R, Hsieh JJ, Berger M, et al. 2018 KMT2C mediates the estrogen dependence of breast cancer through regulation of ERalpha enhancer function. Oncogene 37 4692-4710. (https://doi. org/10.1038/s41388-018-0273-5)

Gasperini M, Hill AJ, McFaline-Figueroa JL, Martin B, Kim S, Zhang MD Jackson D, Leith A, Schreiber J, Noble WS, et al. 2019 A genomewide framework for mapping gene regulation via cellular genetic screens. Cell 176 377.e319-390.e319. (https://doi.org/10.1016/j. cell.2018.11.029)

Geybels MS, Alumkal JJ, Luedeke M, Rinckleb A, Zhao S, Shui IM, Bibikova M, Klotzle B, van den Brandt PA, Ostrander EA, et al. 2015 Epigenomic profiling of prostate cancer identifies differentially methylated genes in TMPRSS2:ERG fusion-positive versus fusionnegative tumors. Clinical Epigenetics 7 128. (https://doi.org/10.1186/ s13148-015-0161-6)

Grasso CS, Wu YM, Robinson DR, Cao X, Dhanasekaran SM, Khan AP, Quist MJ, Jing X, Lonigro RJ, Brenner JC, et al. 2012 The mutational landscape of lethal castration-resistant prostate cancer. Nature $\mathbf{4 8 7}$ 239-243. (https://doi.org/10.1038/nature11125)

Guo Z, Yang X, Sun F, Jiang R, Linn DE, Chen H, Chen H, Kong X, Melamed J, Tepper CG, et al. 2009 A novel androgen receptor splice variant is up-regulated during prostate cancer progression and promotes androgen depletion-resistant growth. Cancer Research 69 2305-2313. (https://doi.org/10.1158/0008-5472.CAN-08-3795)

Haffner MC, Mosbruger T, Esopi DM, Fedor H, Heaphy CM, Walker DA, Adejola N, Gurel M, Hicks J, Meeker AK, et al. 2013 Tracking the clonal origin of lethal prostate cancer. Journal of Clinical Investigation 123 4918-4922. (https://doi.org/10.1172/JCI70354)

He HH, Meyer CA, Chen MW, Jordan VC, Brown M \& Liu XS 2012 Differential DNase I hypersensitivity reveals factor-dependent chromatin dynamics. Genome Research 22 1015-1025. (https://doi. org/10.1101/gr.133280.111)
He Y, Lu J, Ye Z, Hao S, Wang L, Kohli M, Tindall DJ, Li B, Zhu R, Wang L, et al. 2018 Androgen receptor splice variants bind to constitutively open chromatin and promote abiraterone-resistant growth of prostate cancer. Nucleic Acids Research 46 1895-1911.

Hedayati M, Haffner MC, Coulter JB, Raval RR, Zhang Y, Zhou H, Mian O, Knight EJ, Razavi N, Dalrymple S, et al. 2016 Androgen deprivation followed by acute androgen stimulation selectively sensitizes AR-positive prostate cancer cells to ionizing radiation. Clinical Cancer Research 22 3310-3319. (https://doi. org/10.1158/1078-0432.CCR-15-1147)

Heinz S, Benner C, Spann N, Bertolino E, Lin YC, Laslo P, Cheng JX, Murre C, Singh H \& Glass CK 2010 Simple combinations of lineagedetermining transcription factors prime cis-regulatory elements required for macrophage and B cell identities. Molecular Cell $\mathbf{3 8}$ 576-589. (https://doi.org/10.1016/j.molcel.2010.05.004)

Hendriksen PJ, Dits NF, Kokame K, Veldhoven A, van Weerden WM, Bangma CH, Trapman J \& Jenster G 2006 Evolution of the androgen receptor pathway during progression of prostate cancer. Cancer Research 66 5012-5020. (https://doi.org/10.1158/0008-5472.CAN-053082)

Henttu P, Liao SS \& Vihko P 1992 Androgens up-regulate the human prostate-specific antigen messenger ribonucleic acid (mRNA), but down-regulate the prostatic acid phosphatase mRNA in the LNCaP cell line. Endocrinology 130 766-772. (https://doi.org/10.1210/ endo.130.2.1370795)

Hsieh CL, Fei T, Chen Y, Li T, Gao Y, Wang X, Sun T, Sweeney CJ, Lee GS, Chen S, et al. 2014 Enhancer RNAs participate in androgen receptor-driven looping that selectively enhances gene activation. PNAS 111 7319-7324. (https://doi.org/10.1073/ pnas.1324151111)

Hu R, Lu C, Mostaghel EA, Yegnasubramanian S, Gurel M, Tannahill C, Edwards J, Isaacs WB, Nelson PS, Bluemn E, et al. 2012 Distinct transcriptional programs mediated by the ligand-dependent fulllength androgen receptor and its splice variants in castrationresistant prostate cancer. Cancer Research 72 3457-3462. (https://doi. org/10.1158/0008-5472.CAN-11-3892)

International Human Genome Sequencing Consortium 2004 Finishing the euchromatic sequence of the human genome. Nature $\mathbf{4 3 1}$ 931-945. (https://doi.org/10.1038/nature03001)

Isaacs JT 2018 Resolving the Coffey Paradox: what does the androgen receptor do in normal vs. malignant prostate epithelial cells? American Journal of Clinical and Experimental Urology 6 55-61.

Jaitin DA, Weiner A, Yofe I, Lara-Astiaso D, Keren-Shaul H, David E, Salame TM, Tanay A, van Oudenaarden A \& Amit I 2016 Dissecting immune circuits by linking crispr-pooled screens with single-cell RNA-Seq. Cell 167 1883.e15-1896.e15. (https://doi.org/10.1016/j. cell.2016.11.039)

Javierre BM, Burren OS, Wilder SP, Kreuzhuber R, Hill SM, Sewitz S, Cairns J, Wingett SW, Varnai C, Thiecke MJ, et al. 2016 Lineagespecific genome architecture links enhancers and non-coding disease variants to target gene promoters. Cell 167 1369.e19-1384.e19. (https://doi.org/10.1016/j.cell.2016.09.037)

Jin HJ, Zhao JC, Wu L, Kim J \& Yu J 2014 Cooperativity and equilibrium with FOXA1 define the androgen receptor transcriptional program. Nature Communications 5 3972. (https://doi.org/10.1038/ ncomms4972)

Johng D, Torga G, Ewing CM, Jin K, Norris JD, McDonnell DP \& Isaacs WB 2019 HOXB13 interaction with MEIS1 modifies proliferation and gene expression in prostate cancer. Prostate 79 414-424. (https://doi.org/10.1002/pros.23747)

Jozwik KM, Chernukhin I, Serandour AA, Nagarajan S \& Carroll JS 2016 FOXA1 directs H3K4 monomethylation at enhancers via recruitment of the methyltransferase MLL3. Cell Reports 17 2715-2723. (https:// doi.org/10.1016/j.celrep.2016.11.028)

Kari V, Mansour WY, Raul SK, Baumgart SJ, Mund A, Grade M, Sirma H, Simon R, Will H, Dobbelstein M, et al. 2016 Loss of CHD1 causes 
DNA repair defects and enhances prostate cancer therapeutic responsiveness. EMBO Reports 17 1609-1623. (https://doi. org/10.15252/embr.201642352)

Ken-ichi T 2018 The biological role of androgen receptor in prostate cancer progression: advances in testosterone action. InTechOpen [epub]. (https://doi.org/10.5772/intechopen.76360)

Kim J, Lee Y, Lu X, Song B, Fong KW, Cao Q, Licht JD, Zhao JC \& Yu J 2018 Polycomb- and methylation-independent roles of EZH2 as a transcription activator. Cell Reports 25 2808.e4-2820.e4. (https://doi. org/10.1016/j.celrep.2018.11.035)

Korkmaz G, Lopes R, Ugalde AP, Nevedomskaya E, Han R, Myacheva K, Zwart W, Elkon R \& Agami R 2016 Functional genetic screens for enhancer elements in the human genome using CRISPR-Cas9. Nature Biotechnology 34 192-198. (https://doi.org/10.1038/nbt.3450)

Krause WC, Shafi AA, Nakka M \& Weigel NL 2014 Androgen receptor and its splice variant, AR-V7, differentially regulate FOXA1 sensitive genes in LNCaP prostate cancer cells. International Journal of Biochemistry and Cell Biology 54 49-59. (https://doi.org/10.1016/j. biocel.2014.06.013)

Kron K, Trudel D, Pethe V, Briollais L, Fleshner N, van der Kwast T \& Bapat B 2013 Altered DNA methylation landscapes of polycombrepressed loci are associated with prostate cancer progression and ERG oncogene expression in prostate cancer. Clinical Cancer Research 19 3450-3461. (https://doi.org/10.1158/1078-0432.CCR-12-3139)

Kron KJ, Murison A, Zhou S, Huang V, Yamaguchi TN, Shiah YJ, Fraser M, van der Kwast T, Boutros PC, Bristow RG, et al. 2017 TMPRSS2-ERG fusion co-opts master transcription factors and activates NOTCH signaling in primary prostate cancer. Nature Genetics 49 1336-1345. (https://doi.org/10.1038/ng.3930)

Kunderfranco P, Mello-Grand M, Cangemi R, Pellini S, Mensah A, Albertini V, Malek A, Chiorino G, Catapano CV \& Carbone GM 2010 ETS transcription factors control transcription of EZH2 and epigenetic silencing of the tumor suppressor gene Nkx3.1 in prostate cancer. PLoS ONE 5 e10547. (https://doi.org/10.1371/journal. pone.0010547)

Kuznetsova T, Wang SY, Rao NA, Mandoli A, Martens JH, Rother N, Aartse A, Groh L, Janssen-Megens EM, Li G, et al. 2015 Glucocorticoid receptor and nuclear factor kappa-B affect threedimensional chromatin organization. Genome Biology 16264. (https://doi.org/10.1186/s13059-015-0832-9)

Lai J, Kedda MA, Hinze K, Smith RL, Yaxley J, Spurdle AB, Morris CP, Harris J \& Clements JA 2007 PSA/KLK3 AREI promoter polymorphism alters androgen receptor binding and is associated with prostate cancer susceptibility. Carcinogenesis 28 1032-1039. (https://doi.org/10.1093/carcin/bgl236)

Le Dily F \& Beato M 2018 Signaling by steroid hormones in the 3D nuclear space. International Journal of Molecular Sciences 19 E306. (https://doi.org/10.3390/ijms19020306)

Leach DA, Panagopoulos V, Nash C, Bevan C, Thomson AA, Selth LA \& Buchanan G 2017 Cell-lineage specificity and role of AP-1 in the prostate fibroblast androgen receptor cistrome. Molecular and Cellular Endocrinology 439 261-272. (https://doi.org/10.1016/j. mce.2016.09.010)

Li W, Notani D \& Rosenfeld MG 2016 Enhancers as non-coding RNA transcription units: recent insights and future perspectives. Nature Reviews Genetics 17 207-223. (https://doi.org/10.1038/nrg.2016.4)

Lieberman-Aiden E, van Berkum NL, Williams L, Imakaev M, Ragoczy T, Telling A, Amit I, Lajoie BR, Sabo PJ, Dorschner MO, et al. 2009 Comprehensive mapping of long-range interactions reveals folding principles of the human genome. Science 326 289-293. (https://doi. org/10.1126/science.1181369)

Liu T, Ortiz JA, Taing L, Meyer CA, Lee B, Zhang Y, Shin H, Wong SS, Ma J, Lei Y, et al. 2011 Cistrome: an integrative platform for transcriptional regulation studies. Genome Biology 12 R83. (https:// doi.org/10.1186/gb-2011-12-8-r83)
Lomberk G, Blum Y, Nicolle R, Nair A, Gaonkar KS, Marisa L, Mathison A, Sun Z, Yan H, Elarouci N, et al. 2018 Distinct epigenetic landscapes underlie the pathobiology of pancreatic cancer subtypes. Nature Communications 9 1978. (https://doi.org/10.1038/s41467-01804383-6)

Lu J, Lonergan PE, Nacusi LP, Wang L, Schmidt LJ, Sun Z, Van der Steen T, Boorjian SA, Kosari F, Vasmatzis G, et al. 2015 The cistrome and gene signature of androgen receptor splice variants in castration resistant prostate cancer cells. Journal of Urology 193 690-698. (https://doi.org/10.1016/j.juro.2014.08.043)

Lu Y, Sun J, Kader AK, Kim ST, Kim JW, Liu W, Sun J, Lu D, Feng J, Zhu Y, et al. 2012 Association of prostate cancer risk with SNPs in regions containing androgen receptor binding sites captured by ChIP-On-chip analyses. Prostate 72 376-385. (https://doi. org/10.1002/pros.21439)

Luo Z, Rhie SK, Lay FD \& Farnham PJ 2017 A prostate cancer risk element functions as a repressive loop that regulates HOXA13. Cell Reports 21 1411-1417. (https://doi.org/10.1016/j.celrep.2017.10.048)

Maia S, Cardoso M, Pinto P, Pinheiro M, Santos C, Peixoto A, Bento MJ, Oliveira J, Henrique R, Jeronimo C, et al. 2015 Identification of two novel HOXB13 germline mutations in Portuguese prostate cancer patients. PLOS ONE 10 e0132728. (https://doi.org/10.1371/journal. pone.0132728)

Mazrooei P, Kron K, Zhu Y, Mehdi T, Zhou S, Musaddeeque A, Severson TM, Guilhamon P, Armstrong NS, Huang V, et al. 2018 Somatic mutations and risk-Variants converge on cis-regulatory elements to reveal the cancer driver transcription regulators in primary prostate tumors. Cancer Cell [epub]. (https://doi.org/10.2139/ ssrn.3245213)

Massie CE, Lynch A, Ramos-Montoya A, Boren J, Stark R, Fazli L, Warren A, Scott H, Madhu B, Sharma N, et al. 2011 The androgen receptor fuels prostate cancer by regulating central metabolism and biosynthesis. EMBO Journal 30 2719-2733. (https://doi.org/10.1038/ emboj.2011.158)

McNair C, Urbanucci A, Comstock CE, Augello MA, Goodwin JF, Launchbury R, Zhao SG, Schiewer MJ, Ertel A, Karnes J, et al. 2017 Cell cycle-coupled expansion of AR activity promotes cancer progression. Oncogene 36 1655-1668. (https://doi.org/10.1038/ onc.2016.334)

Metzger E, Willmann D, McMillan J, Forne I, Metzger P, Gerhardt S, Petroll K, von Maessenhausen A, Urban S, Schott AK, et al. 2016 Assembly of methylated KDM1A and CHD1 drives androgen receptor-dependent transcription and translocation. Nature Structural and Molecular Biology 23 132-139. (https://doi.org/10.1038/ nsmb.3153)

Mohammed H, D'Santos C, Serandour AA, Ali HR, Brown GD, Atkins A, Rueda OM, Holmes KA, Theodorou V, Robinson JL, et al. 2013 Endogenous purification reveals GREB1 as a key estrogen receptor regulatory factor. Cell Reports 3 342-349. (https://doi.org/10.1016/j. celrep.2013.01.010)

Morova T, Gönen M, Gürsoy A, Keskin Ö \& Lack N 2017 Androgen receptor binding sites are highly mutated in prostate cancer. bioRxiv. (https://doi.org/10.1101/225433)

Mortazavi A, Williams BA, McCue K, Schaeffer L \& Wold B 2008 Mapping and quantifying mammalian transcriptomes by RNA-Seq. Nature Methods 5 621-628. (https://doi.org/10.1038/nmeth.1226)

Mundbjerg K, Chopra S, Alemozaffar M, Duymich C, Lakshminarasimhan R, Nichols PW, Aron M, Siegmund KD, Ukimura O, Aron M, et al. 2017 Identifying aggressive prostate cancer foci using a DNA methylation classifier. Genome Biology 183. (https://doi.org/10.1186/s13059-016-1129-3)

Myung JK, Wang G, Chiu HH, Wang J, Mawji NR \& Sadar MD 2017 Inhibition of androgen receptor by decoy molecules delays progression to castration-recurrent prostate cancer. PLOS ONE 12 e0174134. (https://doi.org/10.1371/journal.pone.0174134) (c) 2019 Society for Endocrinology Published by Bioscientifica Ltd. Printed in Great Britain 
Nash C, Boufaied N, Mills IG, Franco OE, Hayward SW \& Thomson AA 2018 Genome-wide analysis of AR binding and comparison with transcript expression in primary human fetal prostate fibroblasts and cancer associated fibroblasts. Molecular and Cellular Endocrinology 471 1-14. (https://doi.org/10.1016/j.mce.2017.05.006)

Nelson PS, Clegg N, Arnold H, Ferguson C, Bonham M, White J, Hood L \& Lin B 2002 The program of androgen-responsive genes in neoplastic prostate epithelium. PNAS 99 11890-11895. (https://doi. org/10.1073/pnas.182376299)

Paltoglou S, Das R, Townley SL, Hickey TE, Tarulli GA, Coutinho I, Fernandes R, Hanson AR, Denis I, Carroll JS, et al. 2017 Novel androgen receptor coregulator GRHL2 exerts both oncogenic and antimetastatic functions in prostate cancer. Cancer Research $\mathbf{7 7}$ 3417-3430. (https://doi.org/10.1158/0008-5472.CAN-16-1616)

Pang S, Taneja S, Dardashti K, Cohan P, Kaboo R, Sokoloff M, Tso CL, Dekernion JB \& Belldegrun AS 1995 Prostate tissue specificity of the prostate-specific antigen promoter isolated from a patient with prostate cancer. Human Gene Therapy 6 1417-1426. (https://doi. org/10.1089/hum.1995.6.11-1417)

Papachristou EK, Kishore K, Holding AN, Harvey K, Roumeliotis TI, Chilamakuri CSR, Omarjee S, Chia KM, Swarbrick A, Lim E, et al. 2018 A quantitative mass spectrometry-based approach to monitor the dynamics of endogenous chromatin-associated protein complexes. Nature Communications 9 2311. (https://doi.org/10.1038/ s41467-018-04619-5)

Patten DK, Corleone G, Gyorffy B, Perone Y, Slaven N, Barozzi I, Erdos E, Saiakhova A, Goddard K, Vingiani A, et al. 2018 Enhancer mapping uncovers phenotypic heterogeneity and evolution in patients with luminal breast cancer. Nature Medicine 24 1469-1480. (https://doi.org/10.1038/s41591-018-0091-x)

Pihlajamaa P, Sahu B, Lyly L, Aittomaki V, Hautaniemi S \& Janne OA 2014 Tissue-specific pioneer factors associate with androgen receptor cistromes and transcription programs. EMBO Journal 33 312-326. (https://doi.org/10.1002/embj.201385895)

Pomerantz MM, Li F, Takeda DY, Lenci R, Chonkar A, Chabot M, Cejas P, Vazquez F, Cook J, Shivdasani RA, et al. 2015 The androgen receptor cistrome is extensively reprogrammed in human prostate tumorigenesis. Nature Genetics 47 1346-1351. (https://doi. org/10.1038/ng.3419)

Quayle SN, Mawji NR, Wang J \& Sadar MD 2007 Androgen receptor decoy molecules block the growth of prostate cancer. PNAS $\mathbf{1 0 4}$ 1331-1336. (https://doi.org/10.1073/pnas.0606718104)

Quigley DA, Dang HX, Zhao SG, Lloyd P, Aggarwal R, Alumkal JJ, Foye A, Kothari V, Perry MD, Bailey AM, et al. 2018 Genomic hallmarks and structural variation in metastatic prostate cancer. Cell 174 758.e759-769.e759. (https://doi.org/10.1016/j.cell.2018.06.039)

Ram O, Goren A, Amit I, Shoresh N, Yosef N, Ernst J, Kellis M, Gymrek M, Issner R, Coyne M, et al. 2011 Combinatorial patterning of chromatin regulators uncovered by genome-wide location analysis in human cells. Cell 147 1628-1639. (https://doi.org/10.1016/j. cell.2011.09.057)

Ramani V, Deng X, Qiu R, Gunderson KL, Steemers FJ, Disteche CM, Noble WS, Duan Z \& Shendure J 2017 Massively multiplex singlecell Hi-C. Nature Methods 14 263-266. (https://doi.org/10.1038/ nmeth.4155)

Rickman DS, Soong TD, Moss B, Mosquera JM, Dlabal J, Terry S, MacDonald TY, Tripodi J, Bunting K, Najfeld V, et al. 2012 Oncogene-mediated alterations in chromatin conformation. PNAS 109 9083-9088. (https://doi.org/10.1073/pnas.1112570109)

Robinson D, Van Allen EM, Wu YM, Schultz N, Lonigro RJ, Mosquera JM, Montgomery B, Taplin ME, Pritchard CC, Attard G, et al. 2015 Integrative clinical genomics of advanced prostate cancer. Cell 162 1215-1228. (https://doi.org/10.1016/j.cell.2015.05.001)

Ross-Innes CS, Stark R, Teschendorff AE, Holmes KA, Ali HR, Dunning MJ, Brown GD, Gojis O, Ellis IO, Green AR, et al. 2012 Differential oestrogen receptor binding is associated with clinical outcome in breast cancer. Nature 481 389-393. (https://doi. org/10.1038/nature10730)

Rotem A, Ram O, Shoresh N, Sperling RA, Goren A, Weitz DA \& Bernstein BE 2015 Single-cell ChIP-seq reveals cell subpopulations defined by chromatin state. Nature Biotechnology 33 1165-1172. (https://doi.org/10.1038/nbt.3383)

Sahu B, Laakso M, Ovaska K, Mirtti T, Lundin J, Rannikko A, Sankila A, Turunen JP, Lundin M, Konsti J, et al. 2011 Dual role of FoxA1 in androgen receptor binding to chromatin, androgen signalling and prostate cancer. EMBO Journal 30 3962-3976. (https://doi. org/10.1038/emboj.2011.328)

Schmitt AD, Hu M, Jung I, Xu Z, Qiu Y, Tan CL, Li Y, Lin S, Lin Y, Barr CL, et al. 2016 A compendium of chromatin contact maps reveals spatially active regions in the human genome. Cell Reports $\mathbf{1 7}$ 2042-2059. (https://doi.org/10.1016/j.celrep.2016.10.061)

Schoenfelder S, Javierre BM, Furlan-Magaril M, Wingett SW \& Fraser P 2018 Promoter capture Hi-C: high-resolution, genome-wide profiling of promoter interactions. Journal of Visualized Experiments $\mathbf{1 3 6}$ 57320. (https://doi.org/10.3791/57320)

Schumacher FR, Al Olama AA, Berndt SI, Benlloch S, Ahmed M, Saunders EJ, Dadaev T, Leongamornlert D, Anokian E, CiezaBorrella C, et al. 2018 Association analyses of more than 140,000 men identify 63 new prostate cancer susceptibility loci. Nature Genetics 50 928-936. (https://doi.org/10.1038/s41588-018-0142-8)

Setlur SR, Mertz KD, Hoshida Y, Demichelis F, Lupien M, Perner S, Sboner A, Pawitan Y, Andren O, Johnson LA, et al. 2008 Estrogendependent signaling in a molecularly distinct subclass of aggressive prostate cancer. Journal of the National Cancer Institute 100 815-825. (https://doi.org/10.1093/jnci/djn150)

Severson TM, Nevedomskaya E, Peeters J, Kuilman T, Krijgsman O, van Rossum A, Droog M, Kim Y, Koornstra R, Beumer I, et al. 2016 Neoadjuvant tamoxifen synchronizes ERalpha binding and gene expression profiles related to outcome and proliferation. Oncotarget 7 33901-33918. (https://doi.org/10.18632/oncotarget.8983)

Shang Y, Myers M \& Brown M 2002 Formation of the androgen receptor transcription complex. Molecular Cell 9 601-610. (https://doi. org/10.1016/S1097-2765(02)00471-9)

Sharma NL, Massie CE, Ramos-Montoya A, Zecchini V, Scott HE, Lamb AD, MacArthur S, Stark R, Warren AY, Mills IG, et al. 2013 The androgen receptor induces a distinct transcriptional program in castration-resistant prostate cancer in man. Cancer Cell 23 35-47. (https://doi.org/10.1016/j.ccr.2012.11.010)

Sharp A, Coleman I, Yuan W, Sprenger C, Dolling D, Nava Rodrigues D, Russo JW, Figueiredo I, Bertan C, Seed G, et al. 2018 Androgen receptor splice variant-7 expression emerges with castration resistance in prostate cancer. Journal of Clinical Investigation 129 192-208. (https://doi.org/10.1172/JCI122819)

Shenoy TR, Boysen G, Wang MY, Xu QZ, Guo W, Koh FM, Wang C, Zhang LZ, Wang Y, Gil V, et al. 2017 CHD1 loss sensitizes prostate cancer to DNA damaging therapy by promoting error-prone doublestrand break repair. Annals of Oncology 28 1495-1507. (https://doi. org/10.1093/annonc/mdx165)

Simonis M, Klous P, Splinter E, Moshkin Y, Willemsen R, de Wit E, van Steensel B \& de Laat W 2006 Nuclear organization of active and inactive chromatin domains uncovered by chromosome conformation capture-on-chip (4C). Nature Genetics 38 1348-1354. (https://doi.org/10.1038/ng1896)

Singh AA, Schuurman K, Nevedomskaya E, Stelloo S, Linder S, Droog M, Kim Y, Sanders J, van der Poel H, Bergman AM, et al. 2019 Optimized ChIP-seq method facilitates transcription factor profiling in human tumors. Life Science Alliance 2 e201800115. (https://doi. org/10.26508/1sa.201800115)

Spratt DE, Alshalalfa M, Weiner A, Fishbane N, Mehra R, Walter R, Erho N, Dicker A, Freedland SJ, Karnes J, et al. 2018 Transcriptomic heterogeneity of androgen receptor activity in primary prostate cancer: identification and characterization of a low AR-active 
subclass. Journal of Clinical Oncology 36 (Suppl 2) 2. (https://doi. org/10.1200/JCO.2018.36.6_suppl.2)

Stelloo S, Nevedomskaya E, Kim Y, Hoekman L, Bleijerveld OB, Mirza T, Wessels LFA, van Weerden WM, Altelaar AFM, Bergman AM, et al. 2018a Endogenous androgen receptor proteomic profiling reveals genomic subcomplex involved in prostate tumorigenesis. Oncogene 37 313-322. (https://doi.org/10.1038/onc.2017.330)

Stelloo S, Nevedomskaya E, Kim Y, Schuurman K, Valle-Encinas E, Lobo J, Krijgsman O, Peeper DS, Chang SL, Feng FY, et al. $2018 b$ Integrative epigenetic taxonomy of primary prostate cancer. Nature Communications 9 4900. (https://doi.org/10.1038/s41467-018-07270-2)

Stelloo S, Nevedomskaya E, van der Poel HG, de Jong J, van Leenders GJ, Jenster G, Wessels LF, Bergman AM \& Zwart W 2015 Androgen receptor profiling predicts prostate cancer outcome. EMBO Molecular Medicine 7 1450-1464. (https://doi.org/10.15252/ emmm.201505424)

Taberlay PC, Achinger-Kawecka J, Lun AT, Buske FA, Sabir K, Gould CM, Zotenko E, Bert SA, Giles KA, Bauer DC, et al. 2016 Threedimensional disorganization of the cancer genome occurs coincident with long-range genetic and epigenetic alterations. Genome Research 26 719-731. (https://doi.org/10.1101/gr.201517.115)

Takayama K, Kaneshiro K, Tsutsumi S, Horie-Inoue K, Ikeda K, Urano T, Ijichi N, Ouchi Y, Shirahige K, Aburatani H, et al. 2007 Identification of novel androgen response genes in prostate cancer cells by coupling chromatin immunoprecipitation and genomic microarray analysis. Oncogene 26 4453-4463. (https://doi.org/10.1038/sj. onc.1210229)

Takeda DY, Spisak S, Seo JH, Bell C, O'Connor E, Korthauer K, Ribli D, Csabai I, Solymosi N, Szallasi Z, et al. 2018 A somatically acquired enhancer of the androgen receptor is a noncoding driver in advanced prostate cancer. Cell 174 422.e13-432.e13. (https://doi. org/10.1016/j.cell.2018.05.037)

Taylor BS, Schultz N, Hieronymus H, Gopalan A, Xiao Y, Carver BS, Arora VK, Kaushik P, Cerami E, Reva B, et al. 2010 Integrative genomic profiling of human prostate cancer. Cancer Cell 18 11-22. (https://doi.org/10.1016/j.ccr.2010.05.026)

Tewari AK, Yardimci GG, Shibata Y, Sheffield NC, Song L, Taylor BS, Georgiev SG, Coetzee GA, Ohler U, Furey TS, et al. 2012 Chromatin accessibility reveals insights into androgen receptor activation and transcriptional specificity. Genome Biology 13 R88. (https://doi. org/10.1186/gb-2012-13-10-r88)

Thormann V, Rothkegel MC, Schopflin R, Glaser LV, Djuric P, Li N, Chung HR, Schwahn K, Vingron M \& Meijsing SH 2018 Genomic dissection of enhancers uncovers principles of combinatorial regulation and cell type-specific wiring of enhancer-promoter contacts. Nucleic Acids Research 46 2868-2882. (https://doi. org/10.1093/nar/gky051)

Tomlins SA, Mehra R, Rhodes DR, Cao X, Wang L, Dhanasekaran SM, Kalyana-Sundaram S, Wei JT, Rubin MA, Pienta KJ, et al. 2007 Integrative molecular concept modeling of prostate cancer progression. Nature Genetics 39 41-51. (https://doi.org/10.1038/ ng1935)

Tomlins SA, Rhodes DR, Perner S, Dhanasekaran SM, Mehra R, Sun XW, Varambally S, Cao X, Tchinda J, Kuefer R, et al. 2005 Recurrent fusion of TMPRSS2 and ETS transcription factor genes in prostate cancer. Science 310 644-648. (https://doi.org/10.1126/ science.1117679)

Toropainen S, Niskanen EA, Malinen M, Sutinen P, Kaikkonen MU \& Palvimo JJ 2016 Global analysis of transcription in castrationresistant prostate cancer cells uncovers active enhancers and direct androgen receptor targets. Scientific Reports 6 33510. (https://doi. org/10.1038/srep33510)

Ulirsch JC, Nandakumar SK, Wang L, Giani FC, Zhang X, Rogov P, Melnikov A, McDonel P, Do R, Mikkelsen TS, et al. 2016 Systematic functional dissection of common genetic variation affecting red blood cell traits. Cell 165 1530-1545. (https://doi.org/10.1016/j. cell.2016.04.048)

Ulz P, Perakis S, Zhou Q, Moser T, Belic J, Wölfer A, Zebisch A, Gerger A, Pristauz G, Petru E, et al. 2018 Inference of tumor cell-specific transcription factor binding from cell-free DNA. bioRxiv. (https://doi. org/10.1101/456681)

Urbanucci A, Sahu B, Seppala J, Larjo A, Latonen LM, Waltering KK, Tammela TL, Vessella RL, Lahdesmaki H, Janne OA, et al. 2012 Overexpression of androgen receptor enhances the binding of the receptor to the chromatin in prostate cancer. Oncogene $\mathbf{3 1}$ 2153-2163. (https://doi.org/10.1038/onc.2011.401)

Viswanathan SR, Ha G, Hoff AM, Wala JA, Carrot-Zhang J, Whelan CW, Haradhvala NJ, Freeman SS, Reed SC, Rhoades J, et al. 2018 Structural alterations driving castration-resistant prostate cancer revealed by linked-read genome sequencing. Cell 174 433.e19-447. e19. (https://doi.org/10.1016/j.cell.2018.05.036)

Wang D, Garcia-Bassets I, Benner C, Li W, Su X, Zhou Y, Qiu J, Liu W, Kaikkonen MU, Ohgi KA, et al. 2011 Reprogramming transcription by distinct classes of enhancers functionally defined by eRNA. Nature 474 390-394. (https://doi.org/10.1038/nature10006)

Wang Q, Carroll JS \& Brown M 2005 Spatial and temporal recruitment of androgen receptor and its coactivators involves chromosomal looping and polymerase tracking. Molecular Cell 19 631-642. (https://doi.org/10.1016/j.molcel.2005.07.018)

Wang Q, Li W, Liu XS, Carroll JS, Janne OA, Keeton EK, Chinnaiyan AM, Pienta KJ \& Brown M 2007 A hierarchical network of transcription factors governs androgen receptor-dependent prostate cancer growth. Molecular Cell 27 380-392. (https://doi. org/10.1016/j.molcel.2007.05.041)

Wang Q, Li W, Zhang Y, Yuan X, Xu K, Yu J, Chen Z, Beroukhim R, Wang H, Lupien M, et al. 2009 Androgen receptor regulates a distinct transcription program in androgen-independent prostate cancer. Cell 138 245-256. (https://doi.org/10.1016/j. cell.2009.04.056)

Wang X, Qiao Y, Asangani IA, Ateeq B, Poliakov A, Cieslik M, Pitchiaya S, Chakravarthi B, Cao X, Jing X, et al. 2017 Development of peptidomimetic inhibitors of the ERG gene fusion product in prostate cancer. Cancer Cell 31 532.e537-548.e537. (https://doi. org/10.1016/j.ccell.2017.02.017)

Whitington T, Gao P, Song W, Ross-Adams H, Lamb AD, Yang Y, Svezia I, Klevebring D, Mills IG, Karlsson R, et al. 2016 Gene regulatory mechanisms underpinning prostate cancer susceptibility. Nature Genetics 48 387-397. (https://doi.org/10.1038/ng.3523)

Xie S, Duan J, Li B, Zhou P \& Hon GC 2017 Multiplexed engineering and analysis of combinatorial enhancer activity in single cells. Molecular Cell 66 285.e285-299.e285. (https://doi.org/10.1016/j. molcel.2017.03.007)

Xu K, Wu ZJ, Groner AC, He HH, Cai C, Lis RT, Wu X, Stack EC, Loda M, Liu T, et al. 2012 EZH2 oncogenic activity in castrationresistant prostate cancer cells is polycomb-independent. Science $\mathbf{3 3 8}$ 1465-1469. (https://doi.org/10.1126/science.1227604)

Yang R, Browne JA, Eggener SE, Leir SH \& Harris A 2018 A novel transcriptional network for the androgen receptor in human epididymis epithelial cells. Molecular Human Reproduction 24 433-443. (https://doi.org/10.1093/molehr/gay029)

Young CY, Montgomery BT, Andrews PE, Qui SD, Bilhartz DL \& Tindall DJ 1991 Hormonal regulation of prostate-specific antigen messenger RNA in human prostatic adenocarcinoma cell line LNCaP. Cancer Research 51 3748-3752.

Yu J, Yu J, Mani RS, Cao Q, Brenner CJ, Cao X, Wang X, Wu L, Li J, Hu M, et al. 2010 An integrated network of androgen receptor, polycomb, and TMPRSS2-ERG gene fusions in prostate cancer progression. Cancer Cell 17 443-454. (https://doi.org/10.1016/j.ccr.2010.03.018)

Zhang X, Cowper-Sal lari R, Bailey SD, Moore JH \& Lupien M 2012 Integrative functional genomics identifies an enhancer looping to https://erc bioscientifica com

https://doi.org/10.1530/ERC-19-0032
C) 2019 Society for Endocrinology Published by Bioscientifica Ltd. Printed in Great Britain 
the SOX9 gene disrupted by the $17 \mathrm{q} 24.3$ prostate cancer risk locus. Genome Research 22 1437-1446. (https://doi.org/10.1101/ gr.135665.111)

Zhang Z, Chng KR, Lingadahalli S, Chen Z, Liu MH, Do HH, Cai S, Rinaldi N, Poh HM, Li G, et al. 2019 An AR-ERG transcriptional signature defined by long-range chromatin interactomes in prostate cancer cells. Genome Research 29 223-235. (https://doi.org/10.1101/ gr.230243.117)

Zhao D, Lu X, Wang G, Lan Z, Liao W, Li J, Liang X, Chen JR, Shah S, Shang X, et al. 2017 Synthetic essentiality of chromatin remodelling factor CHD1 in PTEN-deficient cancer. Nature 542 484-488. (https:// doi.org/10.1038/nature21357)

Zhao Y, Wang L, Ren S, Wang L, Blackburn PR, McNulty MS, Gao X, Qiao M, Vessella RL, Kohli M, et al. 2016 Activation of P-TEFb by androgen receptor-regulated enhancer RNAs in castration-resistant prostate cancer. Cell Reports 15 599-610. (https://doi.org/10.1016/j. celrep.2016.03.038)

Zhao Z, Tavoosidana G, Sjolinder M, Gondor A, Mariano P, Wang S, Kanduri C, Lezcano M, Sandhu KS, Singh U, et al. 2006 Circular chromosome conformation capture (4C) uncovers extensive networks of epigenetically regulated intra- and interchromosomal interactions. Nature Genetics 38 1341-1347. (https://doi.org/10.1038/ng1891)

Zuber V, Bettella F, Witoelar A, PRACTICAL Consortium, CRUK GWAS, BCAC Consortium, TRICL Consortium, Andreassen OA, Mills IG \& Urbanucci A 2017 Bromodomain protein 4 discriminates tissuespecific super-enhancers containing disease-specific susceptibility loci in prostate and breast cancer. BMC Genomics 18 270. (https://doi. org/10.1186/s12864-017-3620-y)

Received in final form 25 February 2019

Accepted 13 March 2019

Accepted Preprint published online 13 March 2019
(C) 2019 Society for Endocrinology Published by Bioscientifica Ltd. Printed in Great Britain 